\title{
VIC-CropSyst-v2: A regional-scale modeling platform to simulate the nexus of climate, hydrology, cropping systems, and human decisions
}

\author{
Keyvan Malek $^{1, a}$, Claudio Stöckle ${ }^{1}$, Kiran Chinnayakanahalli ${ }^{3}$, Roger Nelson ${ }^{1}$, Mingliang Liu $^{2}$, Kirti Rajagopalan $^{4}$, \\ Muhammad Barik ${ }^{2, b}$, and Jennifer C. Adam ${ }^{2}$ \\ ${ }^{1}$ Department of Biological Systems Engineering at Washington State University, Pullman, Washington, USA \\ ${ }^{2}$ Department of Civil and Environmental Engineering at Washington State University, Pullman, Washington, USA \\ ${ }^{3}$ Air Worldwide Corp., Boston, Massachusetts, USA \\ ${ }^{4}$ Center for Sustaining Agriculture and Natural Resources, Washington State University, Pullman, Washington, USA \\ ${ }^{a}$ currently at: Department of Civil and Environmental Engineering at Washington State University, \\ Pullman, Washington, USA \\ ${ }^{b}$ currently at: University of Alabama in Huntsville, NASA-SERVIR, Huntsville, AL, USA
}

Correspondence to: Keyvan Malek (keyvan.malek@wsu.edu, keyvanmalek@gmail.com) and Jennifer Adam (jcadam@wsu.edu)

Received: 2 December 2016 - Discussion started: 20 December 2016

Revised: 30 June 2017 - Accepted: 3 July 2017 - Published: 17 August 2017

\begin{abstract}
Food supply is affected by a complex nexus of land, atmosphere, and human processes, including short- and long-term stressors (e.g., drought and climate change, respectively). A simulation platform that captures these complex elements can be used to inform policy and best management practices to promote sustainable agriculture. We have developed a tightly coupled framework using the macroscale variable infiltration capacity (VIC) hydrologic model and the CropSyst agricultural model. A mechanistic irrigation module was also developed for inclusion in this framework. Because VIC-CropSyst combines two widely used and mechanistic models (for crop phenology, growth, management, and macroscale hydrology), it can provide realistic and hydrologically consistent simulations of water availability, crop water requirements for irrigation, and agricultural productivity for both irrigated and dryland systems. This allows VICCropSyst to provide managers and decision makers with reliable information on regional water stresses and their impacts on food production. Additionally, VIC-CropSyst is being used in conjunction with socioeconomic models, river system models, and atmospheric models to simulate feedback processes between regional water availability, agricultural water management decisions, and land-atmosphere in-
\end{abstract}

teractions. The performance of VIC-CropSyst was evaluated on both regional (over the US Pacific Northwest) and point scales. Point-scale evaluation involved using two flux tower sites located in agricultural fields in the US (Nebraska and Illinois). The agreement between recorded and simulated evapotranspiration (ET), applied irrigation water, soil moisture, leaf area index (LAI), and yield indicated that, although the model is intended to work on regional scales, it also captures field-scale processes in agricultural areas.

\section{Introduction}

Projected increases in food demand (Godfray et al., 2010) along with other stressors such as droughts and extreme heat events contribute to threats to global food supply (Wheeler and von Braun, 2013). Despite existing research on food scarcity, there are still unanswered questions about the relationship between food supply and the nexus of water resources, agriculture, and human decisions. For example, how expectations of future climatic conditions influence farmer behaviour, such as capital-intensive switches in technology or cropping systems, is not well understood. Such scenar- 
Table 1. Impacts of climate change on crop yield, as discussed by Kurukulasuriya and Rosenthal (2003), Leakey et al. (2009), Reilly (2002), Rosenzweig et al. (2001) and Rowan et al. (2011).

\begin{tabular}{|c|c|c|c|}
\hline Impact factors & Mechanism of impact & $\begin{array}{c}\text { Direction } \\
\text { of impact } \\
\text { on yield }\end{array}$ & References \\
\hline $\mathrm{CO}_{2}$ concentration & $\begin{array}{l}\text { More efficient } \\
\text { photosynthesis } \\
\text { Crop water use efficiency } \\
\text { Nutrient use efficiency }\end{array}$ & $\begin{array}{l}+ \\
+ \\
+\end{array}$ & $\begin{array}{l}\text { Kurukulasuriya and Rosenthal } \\
\text { (2003), Leakey et al. (2009) } \\
\text { Leakey et al. (2009) } \\
\text { Ainsworth and Rogers (2007) }\end{array}$ \\
\hline Temperature & $\begin{array}{l}\text { Water availability for } \\
\text { irrigated agriculture } \\
\text { over snow dominant } \\
\text { basins } \\
\text { Crop growing period length } \\
\text { Planting date } \\
\text { Timing and rate of crop } \\
\text { growth and phenology } \\
\text { Pest and weed growth and } \\
\text { development } \\
\text { Fruit quality }\end{array}$ & $\begin{array}{l} \pm \\
\pm \\
- \\
-\end{array}$ & $\begin{array}{l}\text { Adam et al. (2009); } \\
\text { Barnett et al. (2005); } \\
\text { Elsner et al. (2010); } \\
\text { Mote et al. (2005) } \\
\text { Kurukulasuriya and Rosenthal, } \\
\text { (2003), Dukes and Mooney (1999) } \\
\text { Parry et al. (2005) } \\
\text { Tao et al. (2003) } \\
\text { Kurukulasuriya and Rosenthal } \\
\text { (2003) }\end{array}$ \\
\hline Humidity & $\begin{array}{l}\text { Changes in stomata } \\
\text { functioning }\end{array}$ & + & $\begin{array}{l}\text { Leakey et al. (2009), } \\
\text { Nijs et al. (1997) }\end{array}$ \\
\hline Precipitation & $\begin{array}{l}\text { Changes in soil moisture and } \\
\text { irrigation water resources }\end{array}$ & \pm & Rowan et al. (2011) \\
\hline \multirow[t]{2}{*}{$\begin{array}{l}\text { Frequency of climate } \\
\text { extreme events } \\
\text { (droughts and heat } \\
\text { waves) }\end{array}$} & Crop productivity & - & Rosenzweig et al. (2001) \\
\hline & Water availability for & - & Adam et al. (2009), Barnett \\
\hline
\end{tabular}

ios require a simulation tool that can capture large-scale hydrologic processes while accurately simulating the impacts of climate, management, and water availability on different crop types. Moreover, regional consequences of decisions intended to mitigate the damages of future stressors are not well understood (Robertson and Swinton, 2005). For example, improvement in the efficiency of irrigation systems may increase consumptive water use and lead to a reduction in return flow from irrigated areas (Causapé et al., 2004; Gosain et al., 2005). Return flow plays a significant role in the water availability of many agricultural regions; e.g., $40 \%$ of the water availability at the Yakima River's Parker Gauge in an average year is generated through return flows from upstream lands (USBR, 2010). Ecosystems and hydroelectric generation are also impacted as return flow changes. These knowledge gaps limit our ability to explore viable adaptation strategies, particularly in understanding unintended consequences. Integrated modeling platforms can contribute to the systems-level understanding of dynamics between agricultural processes, large-scale water resource management decisions, and land-atmospheric interactions.
The overall goal of this study is to develop a computational modeling platform that mechanistically captures the interactions between hydrology, crop growth and phenology, and crop and water resource management decisions in the context of global change. Such a platform allows for investigation around multiple objectives: (1) understanding how climate dynamics and land-atmosphere interactions affect water and agricultural sustainability, and (conversely) (2) exploring the role of agricultural (biophysical and socioeconomic) processes in driving land-atmosphere interactions, including climate feedback mechanisms on larger scales.

\subsection{Future food demand and supply}

While over 800 million people throughout the world suffer from undernourishment (FAO, 2013), global change is expected to exacerbate food security problems. The demand for food is increasing due to population growth and changes in food dietary tendency towards higher consumption of meat products (Long et al., 2015). Food supply, however, may not increase as fast as demand (Wheeler and von Braun, 2013), 
as it is affected by complicated interactions between climate, the hydrologic cycle, cropping systems, and human decisions. Table 1 shows the variety of ways that climate change can impact crop yield, with some impacts being positive and others negative; the net result is dependent on region, crop, and future time period. Mechanistic integrated modeling platforms are necessary to assess the net impact of global change on crop production.

\subsection{Interactions between cropping systems, the hydrologic cycle, climate, and human decisions}

Although agricultural productivity is affected by disturbances in the regional cycles of water and energy (Pielke Sr. et al., 2007), agriculture itself feeds back to alter the hydrological cycle by changing evapotranspiration (ET) and the magnitude and temporal regime of soil moisture, infiltration, and runoff generation (Haddeland et al., 2006; Harding et al., 2015; Lu et al., 2015; Sorooshian et al., 2012). The impact of irrigated agriculture on energy and water cycles is particularly important (Ferguson and Maxwell, 2011; Lobell et al., 2009; Pokhrel et al., 2016; Puma and Cook, 2010; Scanlon et al., 2007; Sridhar, 2013). Irrigation uses $70 \%$ of total global water withdrawals (Rost et al., 2008) and boosts soil moisture storage available for crop uptake, and ultimately increases ET. Irrigation losses also increase the amount of deep percolation and runoff (Malek et al., 2017).

While farmers can adjust their management decisions to reduce the negative impacts of climate change (e.g., switching to more efficient irrigation technologies, planting more drought-tolerant crop types or varieties with longer growing periods, and implementing precision agriculture), these human decisions can result in unintended impacts on regional water and energy cycles. The consequences of anthropogenic disturbances (e.g., irrigation withdrawal and dam construction) on the regional water cycle can be greater than the impacts of climate change (Haddeland et al., 2014). Irrigation management and changes in cropping patterns are two examples of management decisions influencing the amount of ET, runoff, deep percolation, and soil moisture, all of which can alter timing and magnitude of return flow. In many agricultural basins, the availability of water for downstream users depends greatly on the return flow from upstream lands, which mainly comes from nonevaporative, reusable loss of water through conveyance systems and field-level application of irrigation water. Therefore, regional-scale simulation of the hydrologic cycle is crucial to the analysis of the impacts of water management in large river basins with significant agricultural activities.

VIC-CropSyst provides an advantage over the stand-alone CropSyst model when run over larger scales. Here, we define large-scale results as regionally aggregated responses of agriculture to changes that can impact scales greater than a single cultivated field, such as a policy change (e.g., water law), climate-related impacts (e.g., warming-induced reductions in summer water availability), or development of large-scale infrastructure (e.g., a large reservoir). Allen et al. (2015) interviewed around 20 stakeholders, including governmental and nongovernmental agency staff and producers, to understand their priorities, concerns, and decision-making processes. They found that many of these stakeholders, including individual producers, are interested in local- and basin-scale information about the impacts of climate change, infrastructural developments, and land management practices on the quantity, quality, and temporal regimes of water resources. Therefore, large-scale integrated modeling platforms are also needed to inform regional natural and agricultural resource management policies and actions.

\subsection{Agricultural processes within macroscale hydrologic models}

\subsubsection{Capturing cropping systems within land surface models}

Land surface models (LSMs) are used for regional- to globalscale simulations of water and energy cycles, often providing terrestrial boundary conditions to general circulation models (GCMs). Results of modeling studies have indicated that, despite the tremendous advances in Earth system modeling, LSMs in their current state are not capable of capturing agricultural processes in a detailed manner (e.g., Chang et al., 2014; Haddeland et al., 2006; Hansen et al., 2006; Lobell et al., 2008, 2009; Ozdogan et al., 2010). In many of them, agricultural processes are similar to natural vegetation (Chang et al., 2014); due to phenological similarities, agricultural lands are often represented by grass vegetation (Elliott et al., 2014). Also, management or harvesting activities as well as $\mathrm{CO}_{2}$ fertilization effects may be ignored (Drewniak et al., 2013). Mitchell et al. (2004) compared the results of four different models and reported poor overall performance among LSMs in capturing warm-season ET. In most cases, this inconsistency can be explained by weak representation of agricultural processes. For example, Schwalm et al. (2010) compared 22 terrestrial biosphere models with North American flux tower sites and found the performance of models in natural vegetation areas to be better than in cropland areas.

Bierkens (2015) reviewed 23 global or large-scale hydrological models (GHMs; e.g., WaterGAP, Verzano et al., 2012; WBMPlus, Wisser et al., 2010; Mac-PDM.09, Gosling and Arnell, 2011; and H08, Hanasaki et al., 2010), LSMs (e.g., VIC, Liang et al., 1994; MATSIRO, Takata et al., 2003; LM3, Milly et al., 2014; NOAH, Liu et al., 2016; JULES, Best et al., 2011; CLM, Fisher et al., 2015; SiB, Baker et al., 2008; and ORCHIDEE, Vérant et al., 2004), and dynamic vegetation models (DVMs; e.g., LPJmL: Biemans et al., 2011; Jägermeyr et al., 2015; Rost et al., 2008). Among these models, H08, MATSIRO and SiB use simple crop growth modules to simulate natural vegetation or generic $\mathrm{C} 3$ and/or 
C4 crops. NOAH, CLM, and LPJmL have more sophisticated crop growth schemes; these are further discussed below.

Using prescribed seasonally and spatially variable leaf area index (LAI) and root density, Wei et al. (2013) modified aerodynamic and soil deficit thresholds in the NOAH land surface model, thereby improving the simulation of warmseason processes. In their model, however, crop growth and development do not mechanistically respond to climate, $\mathrm{CO}_{2}$ concentrations, and soil moisture; this limits the accuracy of model simulation over agricultural areas where the feedback between agricultural processes and hydroclimatic conditions is significant. Liu et al. (2016) improved the simulation of crop processes in the NOAH-MP-Crop model but their model only simulated corn and soybean and did not capture irrigation processes.

Drewniak et al. (2013) enhanced the Community Land Model (CLM) in agricultural areas by using an improved representation of crop processes, but $\mathrm{CO}_{2}$ fertilization effects, irrigation, and other common management activities were neglected. In their simulations, they considered only three crop species (wheat, corn, and soybean) and used a fixed planting date, which can lead to a discrepancy with observations because actual planting dates vary in time as a function of weather (Zeng et al., 2013); this discrepancy can result in an overestimation of the negative impacts of warming on crop yield, as an earlier planting date is a viable adaptation strategy in many regions of the world (Waha et al., 2013). While a newer version of CLM (CLM4-Crop; Lu et al., 2015) simulates irrigation events and $\mathrm{CO}_{2}$ fertilization as well as biomass and vegetation growth processes, its application is also limited to three crop types (Chen et al., 2015) and is not able to mechanistically simulate irrigation efficiency.

Elliott et al. (2014) compared 10 GHMs and 6 global gridded crop models (GGCMs); they reported that the performance of GHMs is generally poor in the simulation of future irrigation water demand. Many of them use prescribed crop growth parameters and did not capture $\mathrm{CO}_{2}$ fertilization or sensitivity to heat and water stresses; the only exception was the Lund-Potsdam-Jena Managed Land Dynamic Global Vegetation and Water Balance Model (LPJmL), which is a hydrologic model that mechanistically simulates both hydrologic and agricultural processes. However, there are some areas where LPJmL is limited for application on finer scales, depending on the research question. Additionally, LPJmL simulates a limited number of crops (Elliott et al., 2014) compared to specialized crop models (e.g., CropSyst and the Decision Support System for Agrotechnology Transfer, DSSAT, Jones et al., 2003). It is also worth mentioning that the scientific community has already benefited from watershed-scale hydrologic-agricultural models. For example, the Soil Water Assessment Tool (SWAT, Arnold et al., 1998; Neitsch et al., 2011) is coupled to a simplified version of the EPIC model (Williams et al., 1983, 1989) and is able to capture agricultural processes and management decisions. SWAT's shortcoming is the fact that it has seven crop classes and does not differentiate among crops within a class (e.g., tree fruits). Furthermore, SWAT uses predefined irrigation losses and does not simulate irrigation processes mechanistically.

\subsubsection{Capturing irrigation systems within land surface models}

Irrigation is one of the important but underappreciated processes in LSMs (Gordon et al., 2008; Ozdogan et al., 2010; Pokhrel et al., 2016). Normally, irrigation processes are treated in LSMs with one of the following approaches.

- Irrigation time and amount are not mechanistically simulated: in most modeling studies, irrigation requirements are calculated using published irrigation guidelines or a time series of satellite observations (Pokhrel et al., 2011). In other models, irrigation water scarcity is not captured (e.g., Ozdogan et al., 2010), which can result in less realistic irrigation management during droughts.

- Irrigation is included but with unrealistic assumptions of irrigation efficiency: for example, CLM v4 simulates the time of irrigation based on soil deficit but does not consider irrigation losses (Leng et al., 2013). This can cause poor representation of hydrologic processes in agricultural areas and underestimation of irrigation demand.

- Partitioning of overall efficiency into different losses through prescribed ratios: Pokhrel et al. (2011) developed an irrigation module and coupled it to the Minimal Advanced Treatments of Surface Interaction and Runoff (MATSIRO) model. The irrigation module considers soil moisture deficit to calculate the time of irrigation, but their irrigation module did not consider the partitioning of the overall efficiency into different losses and did not simulate the dynamics between irrigation losses and the hydrologic cycle.

Haddeland et al. (2006) implemented a simple irrigation module into the VIC model. This irrigation module, however, was limited to prescribed losses of sprinkler systems. Also, because the stand-alone VIC model does not mechanistically simulate crop processes, the timing and amount of irrigation is not responsive to crop growth, management, and phenology.

These shortcomings, simplifying assumptions, and the lack of a mechanistic way to simulate irrigation processes in LSMs lead to inaccurate ET and water demand simulations (Pokhrel et al., 2011; Sridhar, 2013). Also, because LSMs are often coupled to atmospheric models, this lack of captured mechanistic irrigation processes will cause biases in turbulent heat flux simulations, leading to GCM errors. 


\section{Approach}

Here, we introduce the newly integrated model VICCropSyst, which is a coupling between the VIC hydrologic model and the CropSyst crop growth, phenology, and management model. VIC-CropSyst can be used for regional- to global-scale simulations of water and energy cycles over natural and managed terrestrial ecosystems. A process-based irrigation module was also developed to simulate the interactions between irrigation management decisions and the hydrologic cycle in this integrated model (see Malek et al., $2017 \mathrm{a}, \mathrm{b}$ for further information on the irrigation module).

\subsection{Descriptions of stand-alone models}

\subsubsection{VIC}

The VIC model is a process-based large-scale hydrologic model developed initially by Liang et al. (1994). VIC uses the variable infiltration capacity curve introduced by Zhao et al. (1980) to simulate infiltration and surface runoff, and Franchini and Pacciani's (1991) formula to calculate base flow. Liang et al. (1996) further developed the model to represent multiple soil moisture layers (the original version only had two). Cherkauer et al. (2003) added additional sophistication for cold-season processes; further information on the simulation of the snowpack can be found in Andreadis et al. (2009). While the simulation time step of the standalone VIC model can be specified to be daily, hourly, or subdaily (e.g., $3 \mathrm{~h}$ ), in the version of VIC-CropSyst described herein, the simulation time step is currently limited to daily time steps. Subsequent VIC-CropSyst model developments will allow for subdaily time steps. VIC also has the flexibility to be implemented over multiple resolutions (generally at or greater than $1 / 16^{\circ}$ ) and captures subgrid heterogeneity in vegetation, elevation, snow depth, and a variety of other variables. The stand-alone VIC model uses prescribed monthly LAI values to represent seasonal variations of vegetation cover and so does not simulate agricultural processes such as crop development and biomass production and the impacts of water, heat, and nutrient stresses on crop growth. Also, the VIC model does not mechanistically simulate irrigation losses and only includes one type of irrigation (sprinkler; Haddeland et al., 2006). This limits VIC's ability to accurately simulate water demand, transpiration, and agricultural productivity. VIC has been applied and evaluated by several researchers over a variety of areas, e.g., Elsner et al. (2010) and Hamlet and Lettenmaier (1999) over the Columbia River basin (CRB), Adam et al. (2007) in the Eurasian arctic, Maurer et al. (2002) over the contiguous US, and Yuan et al. (2004) over China.

\subsubsection{CropSyst}

CropSyst (Stöckle et al., 1994, 2003) is a process-based cropping system model, capturing water, nitrogen, and carbon cycles as well as the key processes related to crop phenology, root and shoot growth, and biomass production and yield. CropSyst simulates field operations including irrigation, fertilization, tillage, residue management, and crop rotation. It also captures the effects of $\mathrm{CO}_{2}$ concentration and stressors such as water limitation, temperature extremes, and soil salinity on crop development. CropSyst has been applied over a range of climatic conditions worldwide, as well as for climate change studies (e.g., Confalonieri and Bocchi, 2005 for rice in Italy; Ferrer et al., 2000 for corn in Spain; Pala et al., 1996 for wheat in Syria; Karimi et al., 2017 and Pannkuk et al., 1998 for wheat in the US Pacific Northwest; and Alva et al., 2010 for potatoes in the US Pacific Northwest). In CropSyst, the daily biomass production is restricted to the minimum of the two following biomass generation routines: (i) radiation-based biomass production and (ii) transpiration-based biomass production. After simulation of potential biomass, CropSyst takes water, heat, freezing, and nutrient stresses into account to calculate the actual yield. These stresses also modify other crop processes such as transpiration and LAI. Stress sensitivity varies during different phenological periods (e.g., from flowering to maturity). Root occurrence varies in each of the soil layers and depends on the root growth deeper into the soil during biomass development; thus, crop water and nutrient uptake also vary by soil layer. While the start and last date of the growing period is an input to the model, actual crop growth starts after a certain amount of thermal accumulation has been achieved during this user-specified growing period. Crop growth and development is also a function of thermal accumulation, affecting actual harvest date and other growth stages. Additionally, CropSyst uses empirical relationships (Stöckle et al., 1992) to simulate the impact of elevated $\mathrm{CO}_{2}$ concentrations on yield, crop growth, and transpiration.

\subsection{Model integration}

We coupled the VIC version 4.1.2-e with CropSyst-v4.15, although the coupled model will be updated with new versions of VIC and CropSyst as they become available. In a spatially explicit manner, VIC-CropSyst is able to capture a large variety of crop groups: (1) cereal grains (e.g., winter and spring wheat, corn, barley, oats, and sorghum), (2) vegetables and melons (e.g., dill, radish, mint, broccoli, cauliflower, cabbage, carrot, onion, cucumber, pumpkins, and watermelon), (3) fruits and nuts (e.g., plum, apricot, cherry, grape, walnut, pear, peaches, apples, blubbery, strawberry, and cranberry), (4) root crops (e.g., potato and sugar beet), (5) leguminous crops (e.g., green and dry bean, lentil, chickpea, and pea), (6) forages (e.g., pasture, alfalfa, hay, grass, clover, and grass), and (7) oil seeds (e.g., soybean, mustard, and sunflower). In the tightly coupled VIC-CropSyst model (Fig. 1), all hydrologic processes except for transpiration are handled by VIC, while crop growth, transpiration, phenology, and management are handled by CropSyst. In the following sec- 


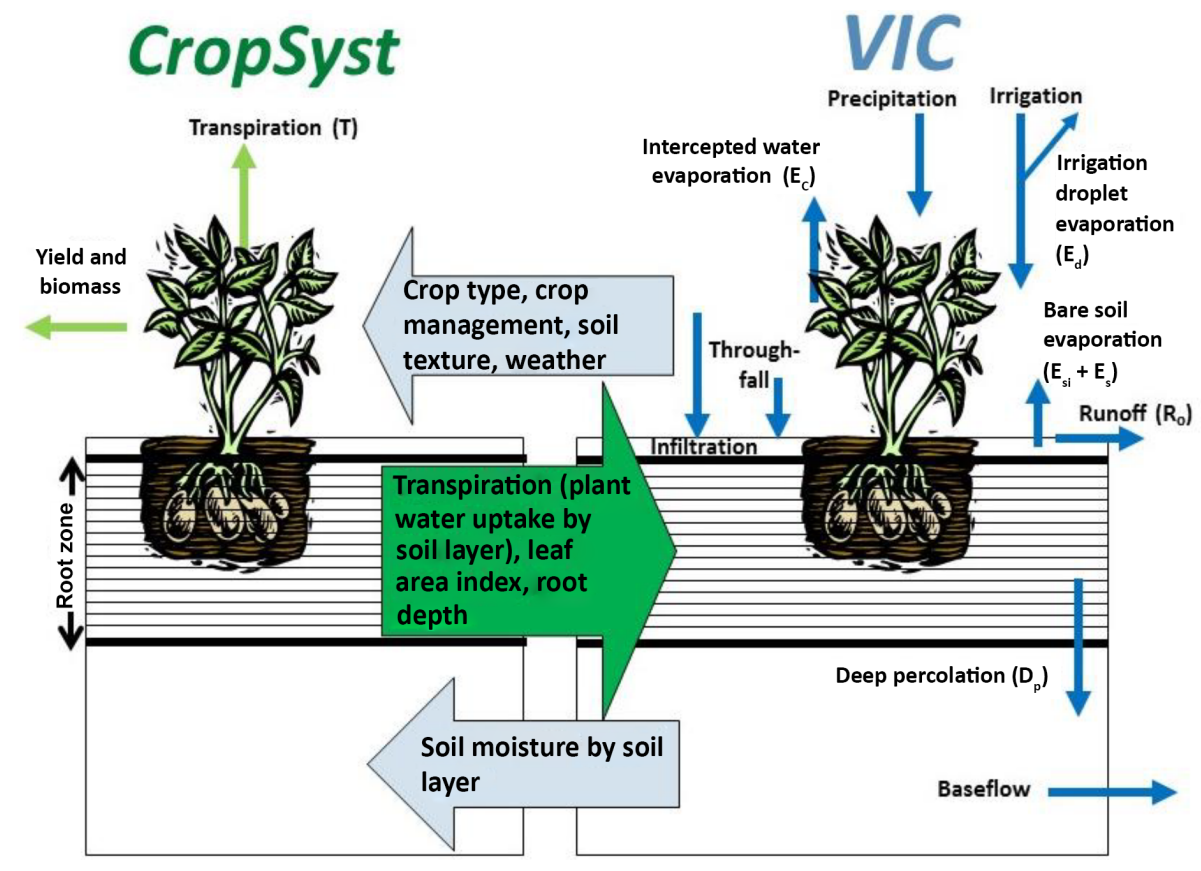

Figure 1. This schematic shows how VIC and CropSyst are coupled. VIC provides the availability of water and energy to CropSyst. CropSyst uses this information to grow the crop, produce biomass and yield, and simulate transpiration. CropSyst passes back the information that is needed by VIC (e.g., the distribution of transpiration uptake in different soil layers, LAI, and root depth) to simulate the hydrologic and energy cycle and the scheduling of irrigation.

tion we explain the structure of the VIC-CropSyst coupling (Fig. 1). Then we discuss some of the changes we have made to each model to support this integration. Finally, we briefly discuss the irrigation module that we have developed and implemented in VIC-CropSyst; full details on the irrigation module can be found in Malek et al. (2017a, b).

\subsubsection{Water and energy balances in VIC-CropSyst}

Figure 2 shows how VIC-CropSyst handles the water and energy budgets. VIC first simulates the energy balance (explained by Cherkauer et al., 2003 and Liang et al., 1994). It estimates available energy per time step and uses an iterative approach to partition the available energy into each of the energy components (e.g., snowmelt and sublimation heat fluxes, ground heat flux, and sensible heat flux). After these terms are calculated, the remaining energy will be available to potential evapotranspiration $\left(\mathrm{ET}_{\mathrm{p}}\right)$. Evaporation can happen from at least one of the five following processes (Thompson et al., 1993): (1) directly from irrigation water $\left(E_{\mathrm{d}}\right)$, (2) from water intercepted by the canopy $\left(E_{\mathrm{c}}\right),(3)$ from the wetted soil surface during irrigation $\left(E_{\mathrm{si}}\right),(4)$ from the soil surface when irrigation is not occurring $\left(E_{\mathrm{s}}\right)$, and (5) through transpiration $(T)$.

CropSyst is called while VIC is simulating the energy balance, but after ETp is portioned into each of its terms. Following this, potential transpiration and availability of soil moisture are passed to CropSyst (Fig. 2). Actual transpiration depends on the availability of soil water. When the soil does not have enough water to meet crop demand, actual crop transpiration is less than potential. In the coupled model, CropSyst simulates actual transpiration, soil water extraction from each layer, water stress, and crop growth; it then passes the extracted soil water amount to VIC to calculate the water balance. VIC updates soil moisture and simulates the rest of the hydrologic components such as runoff and baseflow.

\subsubsection{Significant changes to each model}

- Soil hydrology: in the integrated VIC-CropSyst model, CropSyst's soil hydrology is turned off, allowing VIC to simulate soil hydrologic processes, including the movement of water in soil, bare soil evaporation, and the generation of runoff and baseflow. We did this to retain consistency in all of the hydrologic processes. Stand-alone VIC and CropSyst use different soil hydrologic assumptions to simulate processes related to soil water movement and the generation of runoff and baseflow; these inconsistencies can lead to an inaccurate simulation of irrigation demand and crop productivity. Because crop processes are sensitive to soil moisture availability, we have modified the VIC soil structure. While VIC previously had the capacity to handle an indefinite number of soil moisture layers, the majority of VIC applications utilize three layers, where runoff and baseflow are generated from the top and bottom layers, respec- 


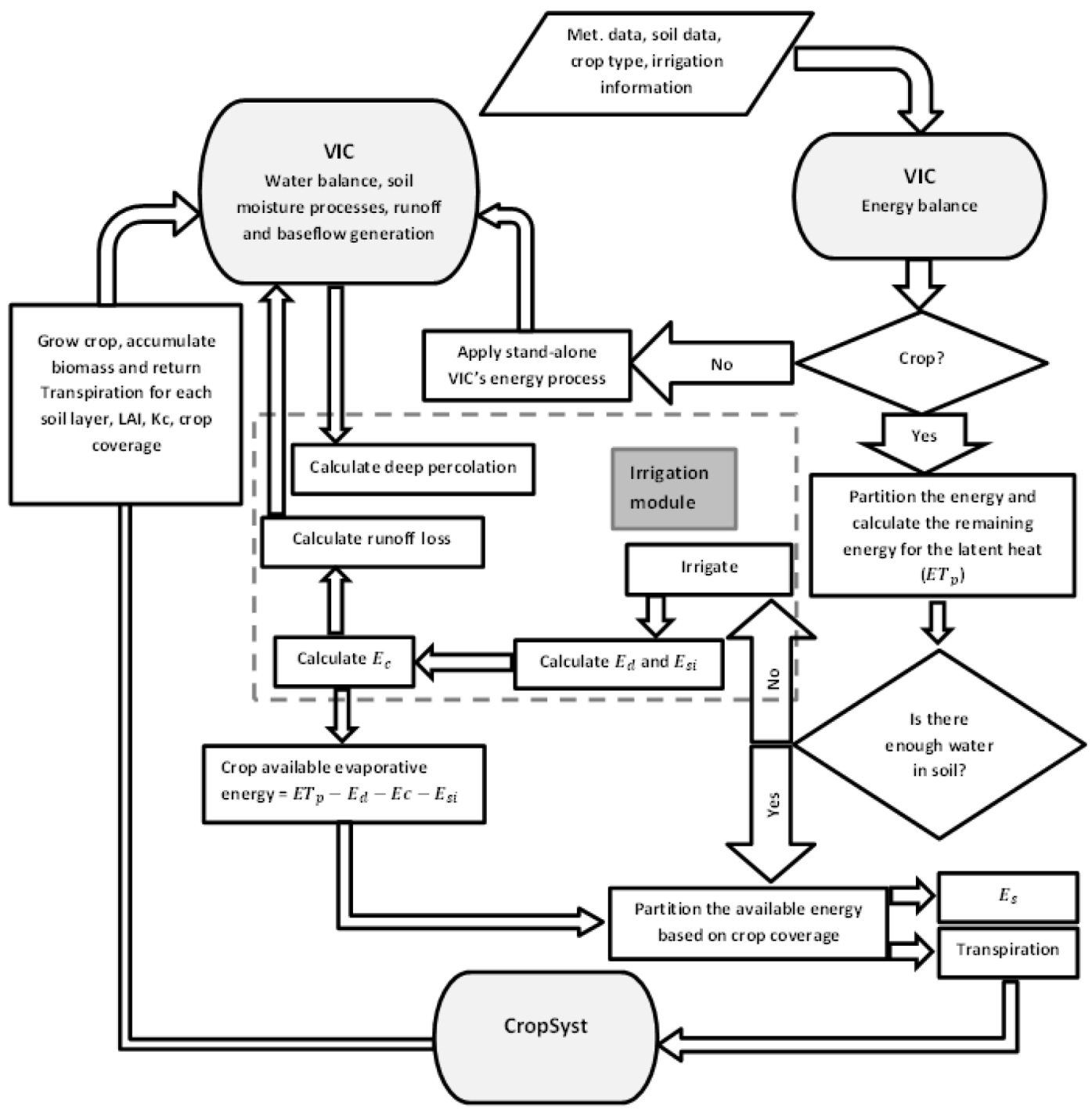

Figure 2. Algorithm used in VIC-CropSyst to partition available energy into different evaporative components. The energy and water balances are handled by the VIC model. CropSyst receives the amount of energy available for transpiration and the availability of water in the soil to determine crop water uptake. VIC needs actual transpiration in different layers of the soil to close the water cycle. Communication between the two models happens for every time step.

tively, while the middle layer is the root zone where plant water uptake occurs. Because the availability of water where roots are concentrated is central to unstressed crop growth, and because the dynamic simulation of root growth is sensitive to the vertical distribution of soil moisture, VIC's conventional three-layer system is too coarse to accurately represent this condition, particularly during droughts and over rain-fed cropland. Therefore, we expanded the middle layer of VIC to 15 layers. Finally, the minimum soil moisture in VIC-CropSyst is set to the wilting point (except in the top evaporative layer where soil evaporation can result in soil moisture levels below wilting point).
- Soil file: the conventional versions of VIC directly read soil properties (e.g., soil hydraulic conductivity, field capacity, wilting point, and bulk density) from input files. For a more consistent way (between VIC and CropSyst) of inputting soil input information, empirical functions developed by Saxton et al. (1986) were implemented in the model and VIC-CropSyst internally estimates the necessary soil parameters using soil textural characteristics (i.e., sand and clay percentages).

\subsection{Irrigation module}

The irrigation module (Fig. 3) is briefly explained below, while a more detailed description can be found in Malek et 


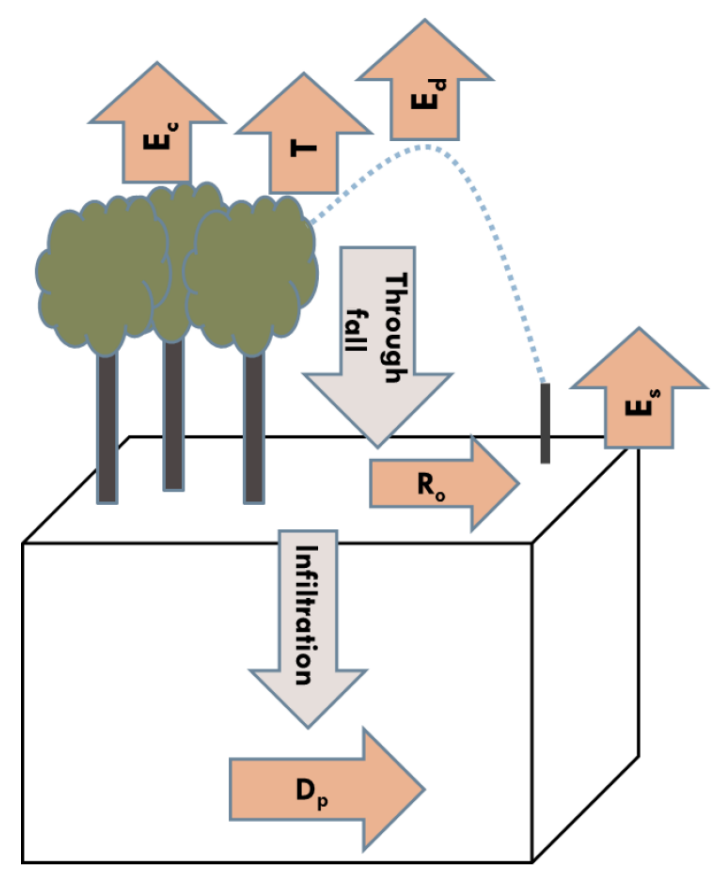

Figure 3. Pathways of irrigation water loss simulated in the irrigation module. $E_{\mathrm{d}}$ : evaporation from irrigation droplets, $E_{\mathrm{c}}$ : evaporation from irrigation water intercepted by canopy, $E_{\mathrm{s}}$ : evaporative loss from soil surface, $D_{\mathrm{p}}$ : deep percolation loss and $R_{\mathrm{O}}$ : irrigation runoff loss. The efficiency of irrigation water is calculated by considering total applied water and all loss terms. $E f=100 \times\left(1-\frac{E_{\mathrm{d}}+E_{\mathrm{s}}+E_{\mathrm{c}}+R_{\mathrm{o}}+D_{\mathrm{p}}}{\text { total irrigation water }}\right)$.

al. (2017a, b). The irrigation module calculates irrigation frequency, amount, and losses.

Currently, VIC-CropSyst simulates four major categories of irrigation systems: surface, center pivot, sprinkler, and drip. Each category includes subcategories. Drip systems include surface and subsurface drip irrigation. In surface drip irrigation, water is applied on the soil surface, while in subsurface drip irrigation, water is applied below the surface and will not lead to any soil evaporative losses. Surface irrigation includes furrow, rill, and border irrigation, and the main difference between these three systems is in their wetted surface area, which is smaller in a furrow system. Center pivots are represented by 18 different types of sprinklers that fall into two subcategories: impact and spray sprinklers. Impact sprinklers generally have a greater discharge rate and wetted radius. Sprinkler systems in VIC-CropSyst include 17 nozzles from three major subcategories: solid set, big gun, and moving wheels. The subcategories differ in terms of discharge, wetted diameter, height, droplet size, and other aspects. The characteristics of these systems have been collected from different scientific papers, reports, and commercial catalogs, including Nelson Co. (2014) and RainBird (2014). This level of detail offers a more accurate representation of irrigation practices, and it will help users to simulate the adaptation of different irrigation and management scenarios.

\subsubsection{Irrigation frequency}

Evaporation, transpiration, and deep percolation cause reductions in root-zone soil water content. When soil moisture deficit reaches one of the following two thresholds, VICCropSyst triggers an irrigation event: (1) capacity of the irrigation system, which sets the maximum amount of water that can be applied in an irrigation event, and (2) the maximum allowable depletion (MAD), which determines what degree of soil dryness causes water stress in each crop. To define crop-specific MADs, we created a table of parameters using FAO-56 (Allen, 1998).

\subsubsection{Evaporative losses}

In the drip and surface categories, evaporative losses happen only from the soil surface because irrigation happens below the canopy level. Irrigation takes place above the canopy in sprinkler and center-pivot systems; therefore, evaporation from canopy-intercepted water $\left(E_{\mathrm{c}}\right)$ and the direct loss from droplets $\left(E_{\mathrm{d}}\right)$ are considered as major irrigation losses. VIC-CropSyst neglects evaporative losses from soil $\left(E_{\mathrm{si}}\right)$ for sprinkler and center-pivot systems because energy is more readily available for water above the canopy and it suppresses the below-canopy evaporation (Uddin et al., 2013; Yonts et al., 2000). Evaporative losses from drip and surface irrigation systems (during irrigation) are based on the following formula:

$E_{\mathrm{si}}=\mathrm{ET}_{\mathrm{p}} A_{\mathrm{w}} T_{\mathrm{i}} / 24$,

where $\mathrm{ET}_{\mathrm{p}}$ is potential ET (mm per $\left.\Delta t\right), A_{\mathrm{w}}$ is the wetted surface fraction during irrigation, and $T_{\mathrm{i}}$ is the time of irrigation (h). While $A_{\mathrm{w}}$ is assumed to be 1.0, 1.0, and 0.5 for border, basin, and farrow irrigation, respectively, we used Malek and Peters' (2011) equation to estimate the wetted radius of drip irrigation and calculate the wetted percentage.

The following formulas are used to calculate $E_{\mathrm{c}}$ and $E_{\mathrm{d}}$ from sprinkler and center-pivot irrigation systems.

- Evaporation of irrigation water intercepted by the crop canopy $\left(E_{\mathrm{c}}\right)$ : to calculate $E_{\mathrm{c}}$, VIC-CropSyst uses the original VIC method (Liang et al., 1994). To avoid overestimation of $E_{\mathrm{c}}$ in agricultural areas, we used the equation developed by Kang et al. (2005) to set the maximum value of $E_{\mathrm{c}}$.

- Evaporation from irrigation droplets $\left(E_{\mathrm{d}}\right)$ : users have the option to calculate $E_{\mathrm{d}}$ using one of the two following methods. 
a. Malek et al. (2017a, b):

$$
\begin{gathered}
E_{\mathrm{d}}=\mathrm{ET}_{\mathrm{p}} \times\left(\frac{1}{D}\right)^{0.52} \times\left(\frac{V_{0} \sin (\theta)}{g}\right. \\
\left.+\frac{\sqrt{V_{0}^{2} \sin ^{2}(\theta)+2 g\left(Y_{0}-Y\right)}}{g}\right)^{1.57},
\end{gathered}
$$

where $Y_{0}(\mathrm{~m})$ is height of nozzle; $Y(\mathrm{~m})$ is canopy height; $V_{0}\left(\mathrm{~m} \mathrm{~s}^{-1}\right)$ is initial velocity of the irrigation water which depends on irrigation system pressure $(\mathrm{H}, \mathrm{m})$, nuzzle coefficient $\left(c_{\mathrm{d}}\right)$, and initial angle of sprinkler $(\theta) ; A_{\mathrm{p}}$ is irrigated area; $D(\mathrm{~mm})$ is the droplet diameter; and $\mathrm{ET}_{\mathrm{p}}(\mathrm{mm} / \Delta t)$ is potential ET.

b. Playán et al. (2005):

for sprinkler : $E_{\mathrm{d}}=20.3+0.214 U^{2}$

$$
-0.00229 \mathrm{RH}^{2} \text {, }
$$

where $\mathrm{RH}(\%)$ is the relative humidity and $U\left(\mathrm{~m} \mathrm{~s}^{-1}\right)$ is wind speed.

\subsubsection{Deep percolation loss $\left(D_{\mathrm{p}}\right)$}

$D_{\mathrm{p}}$ is defined as irrigated water which penetrates below the root zone. Therefore, after an irrigation event the amount of water that enters the base flow layer and becomes inaccessible for crop roots is considered a deep percolation loss.

\subsubsection{Runoff losses $\left(R_{0}\right)$}

$R_{\mathrm{O}}$ depends on soil infiltration rate and irrigation intensity. Whenever irrigation intensity is higher than soil infiltration capacity, runoff is generated as follows:

$R_{\mathrm{o}}=\frac{I_{\mathrm{r}}}{t_{\mathrm{irr}}}-f$

where $f$ is the infiltration rate $\left(\mathrm{mm} \mathrm{h}^{-1}\right), I_{\mathrm{r}}$ is the amount of irrigation water applied in each event $(\mathrm{mm})$, and $t_{\text {irr }}$ is the duration of irrigation (h). Although irrigation intensity is usually a management decision, soil texture and hydraulic conductivity are assumed to be the key considerations in a well-managed irrigation system; therefore, in the beginning of the simulation, VIC-CropSyst estimates the irrigation duration $\left(I_{\mathrm{du}}\right)$ using the soil characteristics of each grid cell. The calculated $I_{\mathrm{du}}$ is used to estimate the infiltration opportunity time of surface irrigation, rotation time in center pivot, and overlap and layout of sprinklers in solid-set, wheel move, and big-gun irrigation systems. If approximated irrigation intensity exceeds the irrigation infiltration rate $(f)$, the extra water generates runoff. VIC-CropSyst uses the equation developed by Philip (1957) to estimate the infiltration rate:

$f=\frac{1}{2} S T_{\mathrm{i}}^{-0.5}+K_{\mathrm{s}}$ where $T_{\mathrm{i}}(\mathrm{min})$ is the elapsed time from the beginning of irrigation, $K_{\mathrm{S}}\left(\mathrm{mm} \mathrm{h}^{-1}\right)$ is the hydraulic conductivity, and $S$ is the sorptivity which is estimated using the Rawls et al. (1992) formula and is calculated based on soil texture and initial water content. Therefore, in VIC-CropSyst, $R_{\mathrm{O}}$ depends on irrigation system, soil type, initial soil moisture, and the intensity of water reaching the soil. Details of the runoff calculations are presented by Malek et al. (2017a, b).

\subsection{Previous versions of VIC-CropSyst}

VIC-CropSyst-v1.0 was originally developed and used to forecast the impact of climate change on CRB water supply and irrigation water demand (Yorgey, et al., 2011; Rajagopalan et al., 2017). This version was created using VIC (v4.0.7) and CropSyst (v4.15). This version is a lower coupling in terms of hydrology, i.e., both models simulate their own soil moisture with different soil parameters and soil layers. While VIC provides the water and cropping information and available energy for ET, partitioning of energy to different evaporative losses (i.e., evaporation from soil and transpiration) is separately done in each model and irrigation evaporative losses are not considered in VIC's energy balance. The irrigation efficiencies were hard-coded in this earlier version. VIC-CropSyst-v1.1 was slightly modified and used by Liu et al. (2013). Rajagopalan et al. (2017) also used VIC-CropSyst-v1.1 to evaluate the impact of climate change on agricultural productivity in the CRB. This paper describes the fully coupled version of the VIC-CropSyst model (version 2). This version is tightly connected in terms of which VIC handles all of the soil hydrologic processes; to do this, some VIC soil processes were altered to be more compatible with CropSyst. Furthermore, the influence of crop transpiration on energy balance is captured in this new version. Finally, this version mechanistically simulates irrigation processes and losses (e.g., irrigation evaporative losses) and is able to apply deficit irrigation.

\subsection{Data and study sites and areas}

VIC-CropSyst's simulated soil moisture, ET, yield, and irrigation water demand were compared to observed data obtained from the FLUXNET network (Baldocchi et al., 2001). Simulated LAI was evaluated against Moderate Resolution Imaging Spectroradiometer (MODIS) remote sensing observations (Cohen et al., 2006). We also evaluated regional performance of VIC-CropSyst in simulation of ET over the US Pacific Northwest, including the states of Washington, Idaho, and Oregon. Other studies such as Malek et al. (2017a, b), Rajagopalan et al. (2017a, b), Barik et al. (2017), Hall et al., 2017), and Yorgey et al. (2011) evaluated VIC-CropSyst in terms of its capability to capture regional irrigation demand, naturalized streamflow, observed streamflow, county-level yield, snow water equivalent, and irrigation efficiency. 


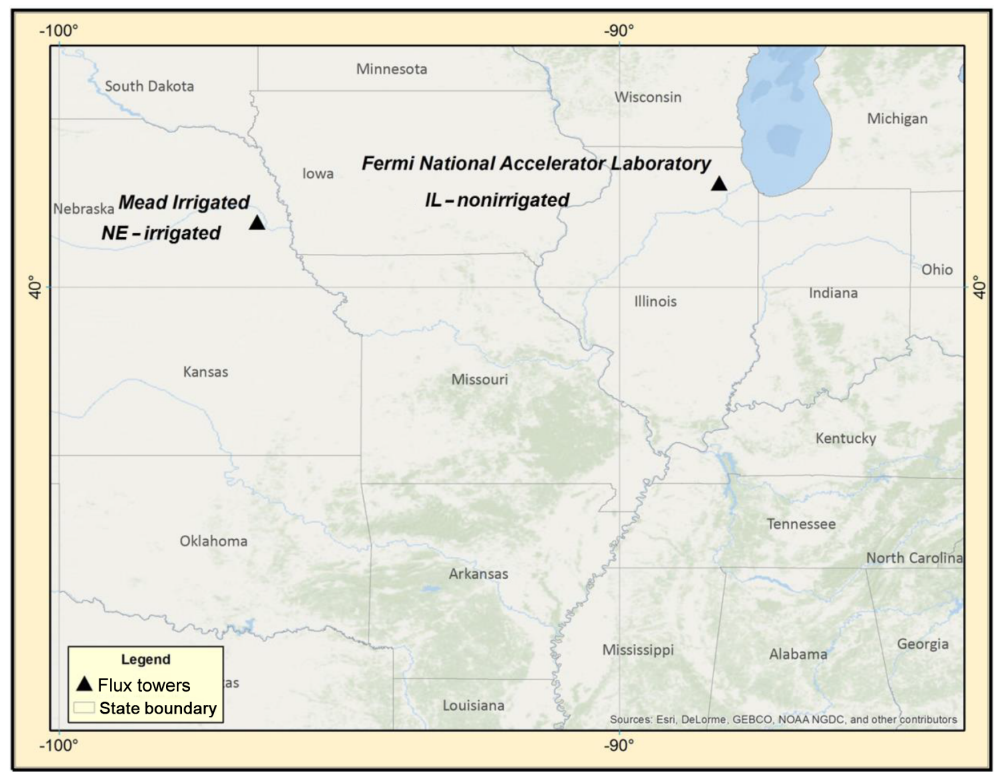

Figure 4. Location of the two flux tower sites in the US, both of which are in agricultural fields. Mead irrigated site (NE) is located in Nebraska; the Fermi National lab site (IL) is located in Illinois; NE is irrigated and the IL is a nonirrigated agricultural site.

\subsubsection{Site description}

The flux tower stations considered in this study are located in the two US states of Nebraska (NE) and Illinois (IL) (Fig. 4). Available environmental and agricultural information include latent heat, soil moisture and meteorological data, crop type, LAI, and biomass production. The towers are all in agricultural fields and have relatively long periods of available data. The station in the IL is not irrigated and the site in NE is irrigated with recorded irrigation frequency and amount.

\subsubsection{Meteorological, soil, land cover, and topographic data}

Daily meteorological data were acquired from the DAYMET (Thornton et al., 2012) gridded data source. Soil files were taken from Maurer et al. (2002) for associated grid cells. We replaced its sand content with data available at the study site. We also added the clay percentages to Maurer et al.'s (2002) soil file. In our simulation, VIC-CropSyst reads the sand and clay content and uses pedotransfer functions developed by Saxton et al. (1986) to generate saturated hydraulic conductivity, bulk density, air entry potential, the $b$ coefficient of Campbell's (1974) soil retention curve, field capacity, wilting point, and porosity. Table 2 shows soil texture calculated using the US Department of Agriculture's soil triangle (GarcíaGaines and Frankenstein, 2015).

\subsubsection{Calibration parameters for point-scale evaluation}

As with other hydrological models, the VIC model needs to be calibrated for optimized performance over a specific region. Table 3 shows VIC's key calibration parameters; more information on calibration parameters and methods can be found in past VIC studies (e.g., Elsner et al., 2010; Liang et al., 1994; and Maurer et al., 2002). We used calibrated parameters determined by Maurer et al. (2002) for each flux tower station (the last two columns of Table 3). We also tested the sensitivity of soil moisture content, crop growth, and irrigation demand and losses to different calibration parameters using the ranges available in the third column of Table 3; differences were negligible.

\subsubsection{Parameterization of growth stages in CropSyst}

Thermal accumulation time in CropSyst is used to represent crop phenological development and the rate of biological activity (McMaster and Wilhelm, 1997). Specifically, the sum of growing degree days (GDDs) is used to specify the time needed to reach specific phenological periods. We parameterized VIC-CropSyst for each site using published dates of crop growth stages (Table 4); meteorological information was used to convert calendar days to GDDs. Peak LAI was acquired from the MODIS LAI product (Cohen et al., 2006). Missing phenological information was estimated from the MODIS-derived peak LAIs as follows: (i) flowering is 2-7 days after peak LAI, (ii) filling starts 7-14 days after flowering, and (iii) maturity happen 30-45 days into the filling period. Table 4 shows estimated or observed dates of the growing stages. 
Table 2. Two flux tower stations used for evaluation of the VIC-CropSyst. The Nebraska site is irrigated using a center-pivot system and the Illinois flux tower station is rain-fed.

\begin{tabular}{|c|c|c|c|c|c|c|c|}
\hline Stations & State & Irrigated & $\begin{array}{l}\text { Cropping } \\
\text { pattern }\end{array}$ & Period & Soil type & $\begin{array}{c}\text { Average } \\
\text { precipitation } \\
(\mathrm{mm})\end{array}$ & $\begin{array}{r}\text { Average } \\
\text { temperature } \\
\left({ }^{\circ} \mathrm{C}\right)\end{array}$ \\
\hline Mead Irrigated & Nebraska (NE) & Yes & Corn & 2001-2008 & Silty clay loam & 789 & 10.1 \\
\hline Fermi National Laboratory & Illinois (IL) & No & Corn/soybean & 2002-2007 & Silty clay loam & 929 & 9.2 \\
\hline
\end{tabular}

Table 3. Calibration parameters used for VIC-CropSyst over the two study sites (columns 5 to 6) and over the Columbia River Basin (CRB). Column 3 represents the ranges of these parameters used for the sensitivity studies.

\begin{tabular}{llrrrr}
\hline Parameter & Description & Range & CRB & NE & IL \\
\hline$b_{\mathrm{i}}$ & $\begin{array}{l}\text { Defines the shape of the variable infiltration } \\
\text { capacity curve that partitions precipitation } \\
\text { into runoff and infiltration }\end{array}$ & $0.001-0.4$ & $0.1-0.3$ & 0.2 & 0.31 \\
& $\begin{array}{l}\text { The fraction of Dsmax where nonlinear baseflow } \\
\text { begins }\end{array}$ & $0.001-0.99$ & $0.001-0.88$ & 0.005 & 0.72 \\
\hline$D_{\mathrm{S}}$ & $\begin{array}{l}\text { The fraction of maximum soil moisture where } \\
\text { nonlinear baseflow occurs }\end{array}$ & $0.4-0.9$ & $0.51-0.91$ & 0.8 & 0.53 \\
\hline$W_{\mathrm{S}}$ & Maximum daily base flow generation & $0.1-30$ & $0.2-10$ & 10 & 28.61 \\
\hline$D_{\text {smax }}$ & & & & & \\
\hline
\end{tabular}

Table 4. Estimated calendar days correspond to each of the growing stages in two study sites. Some of the information is from references listed for each site.

\begin{tabular}{lcccccccc}
\hline $\begin{array}{l}\text { Crop } \\
\text { type }\end{array}$ & Planting & Emergence & $\begin{array}{c}\text { Peak } \\
\text { LAI }\end{array}$ & Flowering & Filling & Maturity & Reference \\
\hline NE & corn & 127 & 140 & 195 & 205 & 225 & 255 & Sakamoto et al. (2010) \\
\hline IL & corn & 125 & 137 & 200 & 208 & 212 & 250 & Nafziger (2013) \\
\hline
\end{tabular}

Table 5. Soil, climate, vegetation and crop information used for regional evaluation of VIC-CropSyst over the US Pacific Northwest. The resolution of the input data was $1 / 16^{\circ}$.

\begin{tabular}{lll}
\hline Input & Source & Information used by VIC-CropSyst \\
\hline Weather & Abatzoglou and Brown (2012) & precipitation, minimum and maximum temperature, and wind speed \\
\hline Soil & STATSGO (Schwarz and Alexander, 1995) & $\begin{array}{l}\text { latitude, longitude, sand and clay content, hydraulic conductivity, field } \\
\text { capacity, bulk density, etc. }\end{array}$ \\
\hline Crop/vegetation & $\begin{array}{l}\text { USDA/WSDA vegetation distribution maps } \\
\text { (Boryan et al., 2011; Yorgey et al., 2011) }\end{array}$ & crop type, acreage, irrigation systems, etc. \\
\hline
\end{tabular}

\subsubsection{Pacific Northwest climate, soil, and crop information}

We used the gridded historical climate data developed by Abatzoglou and Brown (2012), including precipitation, minimum and maximum temperature, and wind speed (Table 5). The soil input file was developed using the STATSGO dataset (Schwarz and Alexander, 1995); to develop the soil file we used the same parameters as Elsner et al. (2010) except we added the clay percentage because, as mentioned earlier, VIC-CropSyst uses Saxton et al.'s (1986) pedotransfer functions and can internally calculate the soil parameters (e.g., hydraulic conductivity, field capacity, and bulk density). The calibration parameters (Table 3) used for simulation of ET over the Pacific Northwest were taken from Yorgey et al. (2011). Crop distribution information over the region was developed using data from Washington State's Department of Agriculture for Washington State and the 


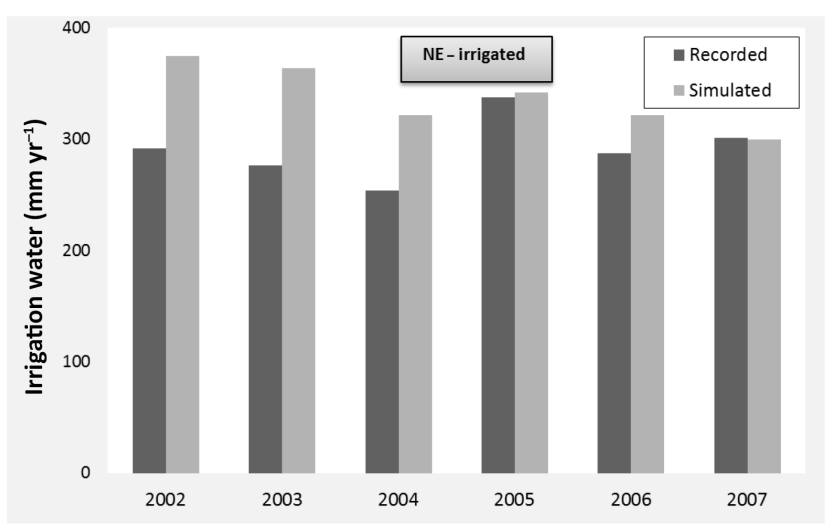

Figure 5. Simulated versus recorded total seasonal irrigation water in an irrigated corn field at the NE flux tower site.

US Department of Agriculture (USDA)'s cropping information for outside of Washington State (Boryan et al., 2011). More information on crop types and crop input parameters (e.g., phenological periods, radiation use efficiency, transpiration use efficiency, and maximum LAI) can be found in Barik et al. (2017), Hall et al. (2017), and Rajagopalan et al. (2017).

\section{Evaluation and application}

\subsection{Point-scale evaluation}

\subsubsection{Applied irrigation water}

Figure 5 compares recorded and simulated irrigation water (mean error $=13 \%)$. Discrepancies may be due to reduction of crop yield in the field due to stresses that are not captured in the model, such as impacts of weed or pests. Also, yields measured in small plots are subject to sampling uncertainty. In addition, simulated irrigation events are likely to include an extra event at the end of the season when irrigation managers stop irrigating earlier due to crop senescence.

\subsubsection{Evapotranspiration (ET)}

Figure 6 depicts the comparisons between monthly simulated and observed ET over irrigated and nonirrigated sites. While the model tends to overestimate ET, particularly during the month with larger ET, simulations are more accurate at the NE irrigated site. Root mean square errors (RMSEs) for the NE and IL stations were 0.8 and $1.0\left(\mathrm{~mm} \mathrm{day}^{-1}\right)$, respectively. In general, the deviation between observed and simulated ET is higher in the summer months. One explanation for this bias is that we do not consider the feedback of evaporative losses from irrigation droplets $\left(E_{\mathrm{d}}\right)$ and canopy-intercepted water $\left(E_{\mathrm{c}}\right)$ to the local microclimate system, while in reality these evaporative losses will lower ambient temperature and decrease vapor pressure deficit (VPD)
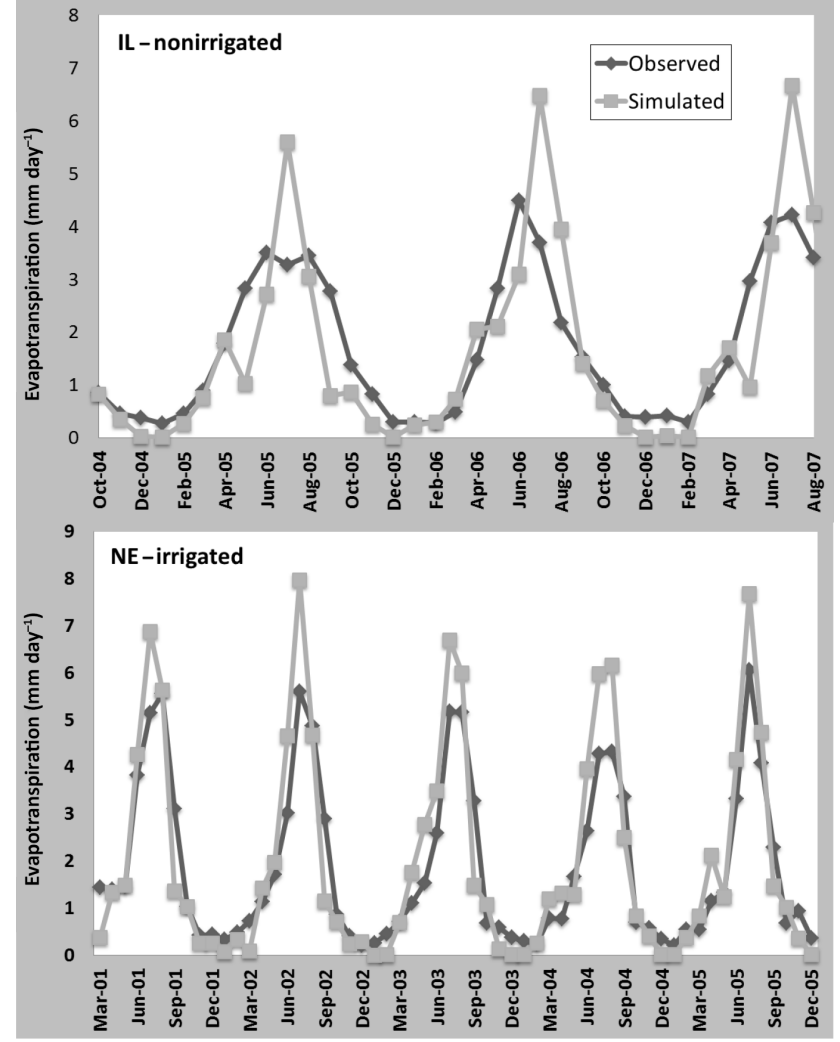

Figure 6. Comparison of simulated and observed corn evapotranspiration (ET; mm day ${ }^{-1}$ ) at two flux tower sites located in NE and IL. The NE site is irrigated while IL is a nonirrigated field.

(Kohl and Wright, 1974; Liu and Kang, 2006), thereby reducing irrigation demand. In the Biosphere-relevant Earth System Model (BioEarth) project (Adam et al., 2014) this shortcoming is being addressed through coupling of VICCropSyst to atmospheric models. Inaccuracy of the meteorological data or uncertainties related to unrecorded management practices, such as deficit irrigation, can be other sources of error. This deviation can also be explained by a typical $20 \%$ systematic error in flux tower ET observations, which tend to underestimate the latent heat fluxes. This energy imbalance issue has been discussed in many studies by the microclimatological community (Frank et al., 2013; Leuning et al., 2012; Mahrt, 1998; Wilson et al., 2002).

\subsubsection{Corn yield}

Figure 7 compares simulated and observed corn yield over the two sites. The mean error of simulated yield for NE (irrigated) and IL (nonirrigated) were 9 and 3\%, respectively. Although Fig. 7 does not show a systematic overestimation by the model, a combination of inaccurate meteorological data, missing processes (e.g., lack of VPD feedback, as discussed in Sect. 3.1.2), and unrecorded conditions such as insufficient irrigation water or heat stress may contribute to these discrep- 


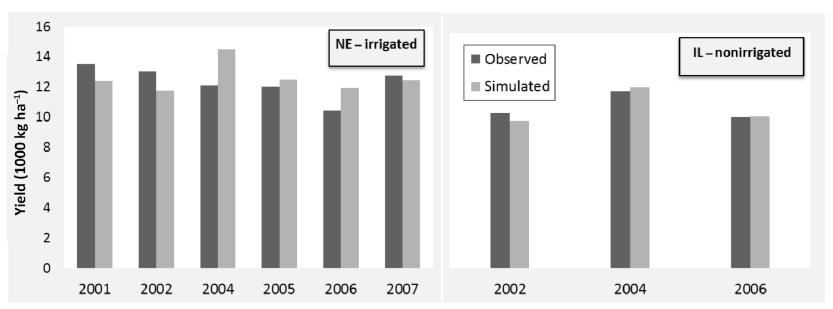

Figure 7. Comparison of simulated and observed corn yield at two flux tower sites for the years during which yield observations were recorded.

ancies. The fact that the error is smaller over the nonirrigated site can be explained by the fact that irrigation management did not have to be simulated, thereby reducing the opportunity for introducing model error.

\subsubsection{Soil moisture}

Figure 8 compares simulated and observed soil moisture over the two sites. Because the soil moisture sensors were placed at 10 and $25 \mathrm{~cm}$ depths at the NE site and at 2.5 and $10 \mathrm{~cm}$ depths at the IL site, we aggregated the first three VIC soil moisture layers (for a total thickness of $30 \mathrm{~cm}$ ) for comparison against observations at the NE site. We compared just the first VIC soil moisture layer $(10 \mathrm{~cm}$ depth) against observations at the IL site. The mean errors were 18 and $16 \%$ for the NE and IL sites, respectively. As with crop yield, soil moisture simulations are better for the nonirrigated site, particularly in terms of variability. The discrepancies may relate to the use of Pedotransfer functions that convert soil textural characteristics to soil hydraulic properties (e.g., field capacity, permanent wilting point, and hydraulic conductivity) for use in VIC-CropSyst (Pachepsky and Rawls, 1999; Tietje and Hennings, 1996). Also, scale discrepancies between the sensors' point-scale observation and the grid-scale simulation (Crow et al., 2012; Robinson et al., 2008) as well as inaccuracy of meteorological and soil data can be other sources of error. Additionally, imperfections in model processes such as soil water movement, ET, and irrigation loss calculation can contribute to the error.

\subsubsection{Leaf area index (LAI)}

Figure 9 shows that VIC-CropSyst is able to capture the magnitude and seasonality of observed LAI, with a slight underestimation of peak LAI. The information we used for calibration of phenological periods is not specifically collected for the two study sites, but instead was based on statescale studies and reports; this is a potential source of error in the simulation of LAI. Because of limited information at flux tower sites, we did not consider all of the crop-related parameters (e.g., radiation use efficiency, maximum crop coefficient, and maximum crop coverage) during calibration,

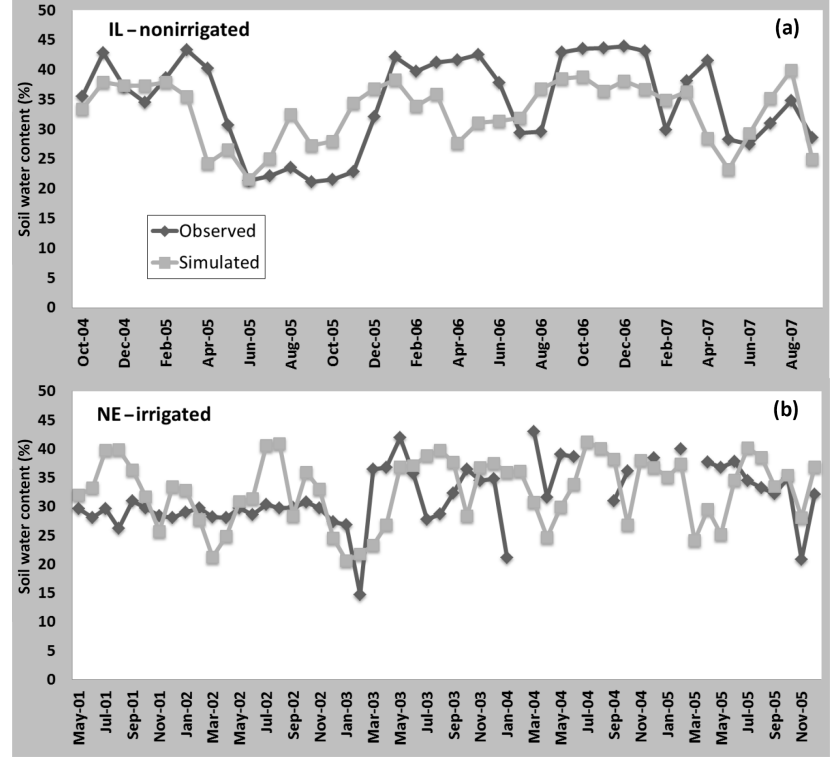

Figure 8. Comparison of simulated and observed soil moisture at the flux tower sites located in IL (a) and NE (b).

which can also lead to some discrepancies (e.g., Jalota et al., 2010; Klein et al., 2012).

\subsection{Regional evaluation of evapotranspiration (ET)}

We used VIC-CropSyst to simulate ET over the CRB portions of three states: Washington, Idaho and Oregon (Fig. 10). Simulated ET was aggregated from the original model resolution of $1 / 16$ to $1 / 2^{\circ}$ for comparison against the upscaled ET product derived from the FLUXNET eddy tower network (Baldocchi et al., 2001). Liu et al. (2013) described the details of the creation of the empirically derived or "observed" ET map. They also compared the observed ET with an offline (from CropSyst) version of VIC-simulated ET and reported a systematic underestimation of simulated ET over warm irrigated areas. Our ET results show that VICCropSyst's simulated ET in general produces a lower error compared to VIC-offline, especially over irrigated areas; error over irrigated landscapes was reduced from about 28 to $17 \%$, a $40 \%$ reduction. However, it is important to note that another source of the discrepancy is due to inaccuracy of the observed ET product because it was developed using a limited number of flux tower stations as well as empirical formulas that also have inherent errors (see Liu et al., 2013 for details).

\subsection{Regional evaluation of crop yields and irrigation demands}

Rajagopalan et al. (2017) performed an evaluation of county level aggregated irrigated crop yields against NASS crop yield statistics, and a comparison of average modelled irriga- 


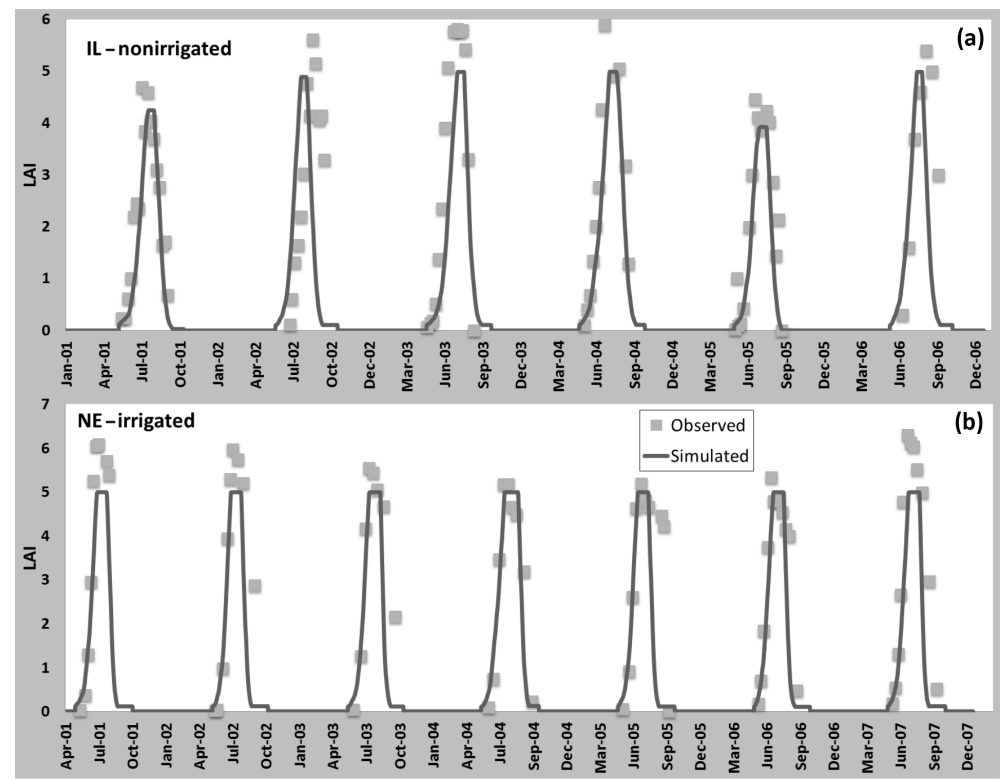

Figure 9. Comparison of simulated and observed corn LAI over two flux tower sites located in IL (a) and NE (b).

tion demands from the Columbia Basin Project area to irrigation diversions. The mean annual yields between observed and simulated values are in agreement with relative errors less than $\pm 5 \%$. On average, the model-simulated annual irrigation demands where about $20 \%$ less than diversions. Part of this difference can be explained by the fact that diversions account for conveyance and seepage losses in the distribution system.

\section{Discussion}

\subsection{Examples of VIC-CropSyst application}

\subsubsection{Simulation of agricultural adaptation in response to climate change}

Farmers adapt their agricultural management to minimize unfavourable impacts of stressors such as climate change (Kurukulasuriya and Rosenthal, 2003). Possible agricultural adaptation strategies have been discussed (e.g., Anwar et al., 2013; Howden et al., 2007; Kurukulasuriya and Rosenthal, 2003; Smit and Skinner, 2002; Smith et al., 2000). However, lack of appropriate simulation tools to assess the effectiveness of an adaptation decision while capturing complex regional impacts is a significant shortcoming. VIC-CropSyst simulates common adaptation strategies used by farmers, and captures the consequences of these adaptation strategies on local and regional hydrology and land-atmosphere interactions. Table 6 shows a list of adaptation decisions that can be handled by VIC-CropSyst. These decisions range from short-term tactical (T) to long-term strategic (L) decisions.

\subsubsection{Foundation for integration within other modeling platforms}

VIC-CropSyst can be used with other modeling frameworks such as river routing, water management, atmospheric, and socioeconomic models. Many of these integrations simulate the human-land-climate nexus and provide scientists, stakeholders and policy makers with a broader understanding of the interactions of and feedbacks between human decisions and the Earth system. VIC-CropSyst has been already used and implemented in various projects; examples are as follows.

\section{Water resource management and socioeconomic studies}

VIC-CropSyst has been used in conjunction with reservoir operation models in the CRB. For example, Rajagopalan et al. (2017) utilize such a platform to assess the impacts of climate change on agricultural production; this includes both the direct impacts of climate change (precipitation, temperature, and $\mathrm{CO}_{2}$ ) and the indirect impacts through changes in the availability of surface water used for irrigation. In assessing the indirect effects through changes in water availability, the authors have incorporated water rights curtailment into the integrated platform (Rajagopalan et al., 2017). The current version of VIC-CropSyst (v2, as described herein) was also used in the most recent CRB long-term studies on water supply and demand for the 2030s (Barik et al., 2017; Hall et al., 2017). These water supply and demand studies were submitted to the Washington State Legislature in the years of 2011 (Yorgey et al., 2011) and 2016 (Hall et al., 2017) and provide detailed information for each watershed in eastern Washington in addition to the entire CRB as a whole. This in- 

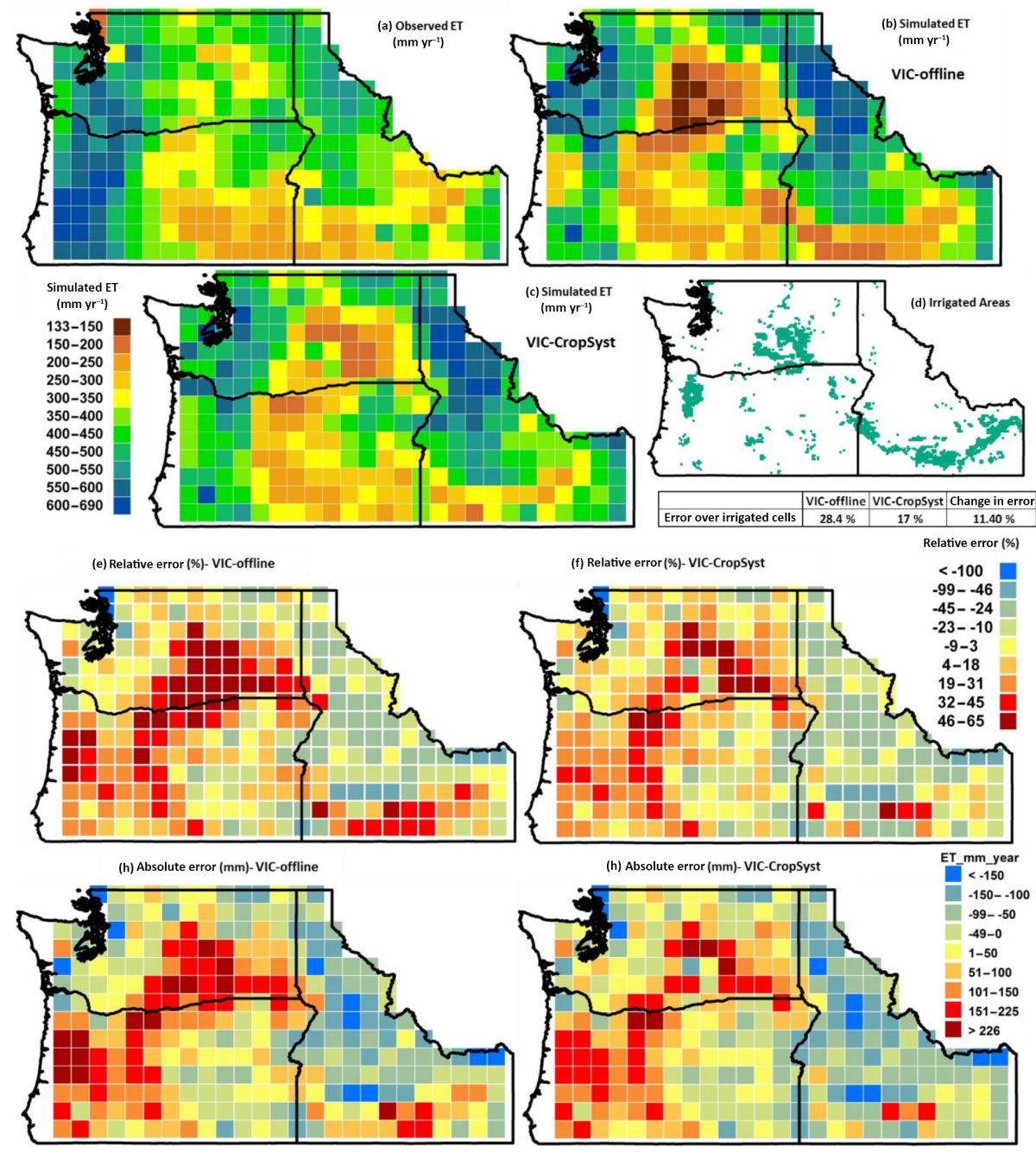

Figure 10. Comparison of simulated and empirically derived ET over the US Pacific Northwest. The simulation and observation period is 1982-2008. Panel (a) shows observed ET (Liu et al., 2013), and (b) and (c) show the simulated ET using VIC-offline and VIC-CropSyst, respectively. Panel (d) shows where the irrigated areas are located in these three states. Panels (e)-(h) show relative and absolute errors of simulated ET by VIC-offline and VIC-CropSyst.

formation is being used by the legislature for long-term water supply planning.

VIC-CropSyst has been used to investigate different scenarios for renegotiation of the Columbia River Treaty (Rushi et al., 2016). Existing modeling efforts to date have focused primarily on the impact that treaty renegotiation would have on flood risk, hydropower generation, and environmental flows (Cosens, 2010; Hamlet and Lettenmaier, 1999); assessment of the impact of CRT changes on irrigated agriculture along the Columbia main stem is a knowledge gap. Therefore, Rushi et al. (2016) applied VIC-CropSyst linked to ColSim (Hamlet and Lettenmaier, 1999) to simulate the complex impacts of climate change and the Columbia River Treaty on hydrology and agriculture in the river basin and concluded that climate change (i) shifts water supply towards earlier in the season, (ii) reduces flood risk in the upper CRB while increasing frequency and magnitude of floods in the middle and lower parts of the basin, (iii) shifts water demand to earlier in the season in some locations with mixed effects on water rights curtailment risk, and (iv) reduces hydropower generation. The authors found that the considered CRT scenarios can improve power generation and agricultural water demand while preventing floods in an altered climate.

VIC-CropSyst is an effective tool for studying the largescale aggregated impacts of local management decisions and phenomena. For example, VIC-CropSyst was applied by Malek et al. (2017a, b) who found that climate changeinduced increases in evaporative (consumptive) losses from irrigation systems and decreases in nonevaporative irrigation losses (i.e., runoff and deep percolation) would lead to a decrease in reusable return flow, which would negatively affect basin-wide water availability and productivity. 
Table 6. Summary of adaptation strategies that can be handled by VIC-CropSyst: the modeling platform is able to simulate the impacts of local decisions on agricultural productivity and at the same time capture the impacts of these decisions on regional land-atmosphere interactions and surface water availability in the basin.

\begin{tabular}{|c|c|c|c|}
\hline & Adaptation strategy & Timing $^{1}$ & Duration $^{2}$ \\
\hline 1 & \multicolumn{3}{|c|}{ Crop-related adaptation strategies } \\
\hline & (i) crop choice and rotation & $\mathrm{R}^{1}$ & $\mathrm{~L}$ \\
\hline & (ii) cropping acreage and location of cropping activities & $\mathrm{R}$ and $\mathrm{A}$ & $\mathrm{L}$ \\
\hline & (iii) timing of planting and harvesting date & $\mathrm{C}$ and $\mathrm{A}$ & $\mathrm{T}$ \\
\hline & (iv) using a new variety of the same crop & $\mathrm{R}$ & $\mathrm{L}$ \\
\hline \multirow[t]{2}{*}{2} & \multicolumn{3}{|c|}{ Long-term strategic water management adaptations } \\
\hline & (i) irrigation system or nozzle & $\mathrm{R}$ and $\mathrm{A}$ & $\mathrm{L}$ \\
\hline \multirow[t]{3}{*}{3} & \multicolumn{3}{|c|}{ Seasonal adaptations to respond to altered water deficit and temporal availability of water } \\
\hline & (i) deficit irrigation magnitude & $\mathrm{C}$ & $\mathrm{T}$ \\
\hline & (ii) deficit irrigation timing in a season & $\mathrm{C}$ & $\mathrm{T}$ \\
\hline 4 & \multicolumn{3}{|c|}{ Short-term tactical adaptation to minimize the impacts of heat stress } \\
\hline & (i) supplementary/over-irrigation & & $\mathrm{T}$ \\
\hline & (ii) irrigation frequency & $\mathrm{C}$ & $\mathrm{T}$ \\
\hline & (iii) irrigation intensity & $\mathrm{C}$ & $\mathrm{T}$ \\
\hline
\end{tabular}

${ }^{1}$ According to Smit and Skinner (2002), the timing of adaptation decision can be A - anticipatory (proactive), C concurrent (during), or R - responsive (reactive). ${ }^{2}$ Duration of adaptive actions can be short-term tactical (T) and long-term strategic (L) (Smit and Skinner, 2002).

VIC-CropSyst has also been used over the Yakima River Basin (YRB) to evaluate the impacts of climate change on decisions related to investment in irrigation technology (Malek et al., 2017a, b). Economic damages of future, more frequent droughts (Vano et al., 2010) are considered the main incentive to invest in more efficient irrigation technology (Berger and Troost, 2014). To analyze future changes in regional irrigation patterns, Malek et al. (2017a, b) used VIC-CropSyst in conjunction with an economic model and the RiverWare model (Zagona et al., 2001). Figure 11 shows a result of this integration to simulate historical (1981-2006) drought frequency and severity, and the percentage of the YRB's perennial crop growers who are simulated to switch to more efficient irrigation systems to minimize the negative consequences of droughts during the two decades of 1990-2000 and 2050-2060. Also, any changes in agricultural activities (e.g., switching to a new irrigation system) directly impacts the hydrology of agricultural fields, thus changing return flow timing and magnitude and the availability of water for downstream users; these downstream consequences can also be simulated by this modeling platform. This is an example of how the human-land-climate nexus can be captured through a modeling framework that simulates large-scale hydrologic processes and regional water availability in a highly cultivated basin, while capturing the dynamics of farm-level irrigation decisions.
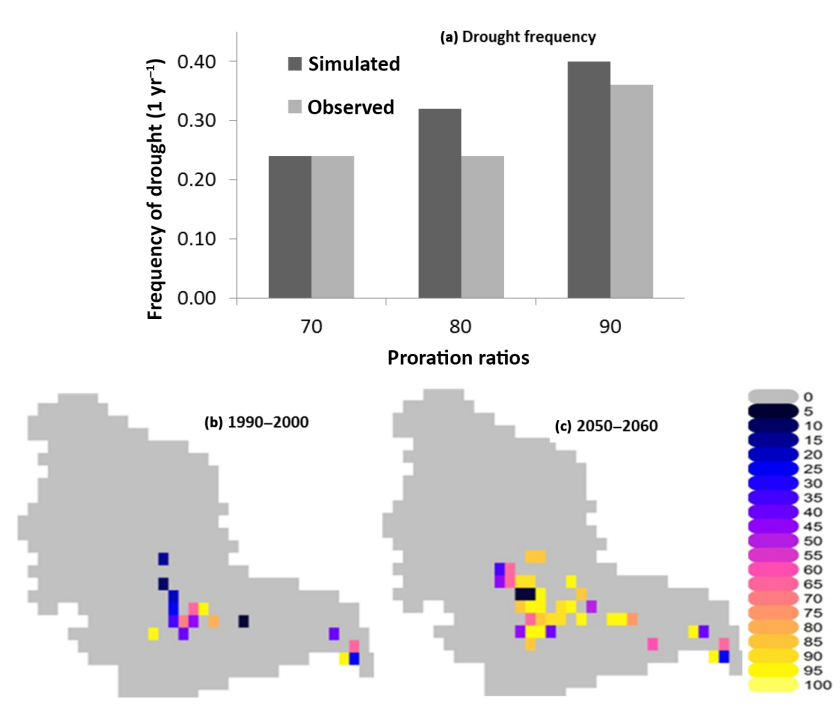

Figure 11. Regional application of VIC-CropSyst in conjunction with a river system model (YAK-RW; Hubble, 2012; Zagona et al., 2001) and an economic model to simulate historical (19812006) drought frequency (a), when the percentage of the water allocated for the irrigation season (i.e., proration rate) is lower than 70, 80, and $90 \%$. Panels (b) and (c) (Malek et al., 2017b) show the percentage of farmers (perennial crop growers) who invest in new efficient irrigation technologies in response to simulated droughts during the two decades of 1990-2000 (b) and 2050-2060 (c). 


\section{Land-atmosphere interactions}

Irrigation and other agricultural decisions modify local to regional climate through changes in land surface conditions such as temperature, water vapor content, and albedo (Fernández et al., 2001; Liu and Kang, 2006). This phenomena can be used to compensate for the negative impacts of heat stress (Lobell et al., 2008), which will be especially important in the future if there are more severe and frequent extreme events related to climate change (Long and Ort, 2010). These management decisions will also impact the regional water cycle, potentially leading to disruption in water availability (Adamson and Loch, 2014) and modifying fluxes of water to the atmosphere (Pielke Sr. et al., 2007). As a part of the BioEarth platform (Adam et al., 2014), VIC-CropSyst is being coupled to an atmospheric model, the Weather Research and Forecast model (WRF; Michalakes et al., 2005; Skamarock et al., 2008), that can be used to quantify the impacts of irrigation and other agricultural management on atmospheric processes, as well as to assess how irrigation management can be used to mitigate heat stress.

\subsection{Simulation of deficit irrigation scenarios}

Although the results presented in this article do not include results related to deficit irrigation during times of water shortage, VIC-CropSyst is able to simulate the impacts of deficit irrigation on hydrologic and cropping systems. VICCropSyst's deficit irrigation module requires two main inputs: (a) a first approximation to the irrigation water demand obtained by generating time series of irrigation in a zero water stress condition using VIC-CropSyst and (b) deficit fractions that indicate the actual water availability as a function of the crop water requirement. VIC-CropSyst then reads the amount of recorded irrigation from step one and applies the deficit fraction to simulate the agricultural and hydrologic processes under realistic water deficit conditions. The deficit fraction can be either homogenously applied across the entire basin or separately specified for each farmer depending on water rights or other considerations. Also, VIC-CropSyst can apply the deficit fraction during different times of the year. For example, if the water deficit happens later in the season, VIC-CropSyst can adjust irrigation amounts according to the timing of water shortage.

VIC-CropSyst has also been used in conjunction with reservoir models (e.g., ColSim: Hamlet and Lettenmaier, 1999, and YAK-RW: Zagona et al., 2001) to calculate the deficit irrigation fraction (e.g., Barik et al., 2017; Malek, et al., 2017a, b; and Rajagopalan et al., 2017). In general, the following six steps can be used to calculate and apply a deficit fraction: (1) VIC-CropSyst simulates the hydrologic states such as runoff and base flow as well as the irrigation water demand, (2) a routing model (Lohmann et al., 1998) is used to simulate streamflow, (3) simulated flow is biascorrected against observed flow, (4) a river system model is used to include operation of dams and reservoir and estimate water availability, (5) the availability of water is compared with water demand, and (6) a deficit fraction is calculated and VIC-CropSyst is run to simulate the impacts of an irrigation deficit on the hydrologic cycle and on crop yields.

\subsection{Model selection considerations}

Which model to apply for a specific research question at hand is dependent on a variety of factors, including geographical considerations but also the level of sophistication needed to address the question. For example, areas with significant irrigation activities can be more precisely simulated with mechanistic irrigation models, or areas with cold climate would necessitate models with more sophisticated cold-season processes. Also, regional agricultural economic studies require a reliable simulation of crop yield for economically significant crops grown in the region. Therefore, models that simulate generic $\mathrm{C} 3$ and/or $\mathrm{C} 4$ crops are not the best option for this type of question. VIC-CropSyst and LPJML are two examples of models that can be used to answer this type of question. Moreover, some of the models have been already tested and used for a particular region and resolution, which naturally makes them more reliable for that specific situation.

\section{Conclusions}

Meeting future food demand will require an extensive understanding of the interactions between agricultural and other systems, such as water resource planning and management as well as socioeconomic and atmospheric processes. The main purpose of this study was to develop the VIC-CropSyst platform that provides tightly integrated and mechanistic representation of both cropping systems and water and/or energy cycles on regional to global scales. Tight integration between VIC and CropSyst necessitated modification of both models, including how the models handle soil movement and vertical distribution, transpiration, LAI, and irrigation. Evaluation of VIC-CropSyst over two flux tower sites shows that the coupled model captures key agronomic and hydrologic states and fluxes on the field scale. Furthermore, implementation of VIC-CropSyst over the US Pacific Northwest region reduced ET simulation error by $40 \%$ over irrigated landscapes.

The VIC-CropSyst platform enables the land surface modeling community to investigate a variety of agricultural management decisions, including crop choice, planted acreage, planting and harvesting date, and multiple irrigation management options. In particular, the new mechanistic irrigation model, which is tightly coupled with both the energy and water cycles, can be used to address questions related to the interaction of climate, hydrology, river basin water management, and irrigation management strategies.

VIC-CropSyst can be integrated with different modeling platforms to capture the dynamics of the human-land- 
climate nexus. This can potentially improve the understanding of environmental processes in highly cultivated basins and can be used to investigate best management practices to promote future sustainability of agricultural production while preserving water resources and minimizing the negative intended and unintended consequences of human actions. Some examples of these implementations are as follows:

- Coupling with water resource management and socioeconomic models: this involves simulating regional water availability and agricultural productivity, adaptive responses of farmers to climate change, and unintended consequences of these adaptation decisions.

- Coupling with weather and climate models: VICCropSyst will also provide capabilities to investigate the dynamics of agricultural management decisions on local to regional weather and climate patterns through modifications of energy and water fluxes (Barnston and Schickedanz, 1984; Douglas et al., 2009; Kohl and Wright, 1974). This promotes the understanding of, for example, how irrigation management and technology can control negative impacts of heat and water stresses on crop yield.
VIC-CropSyst is being used in Earth system models (EaSMs) such as BioEarth (Adam et al., 2014) and can be implemented in other EaSMs, such as the Platform for Regional Integrated Modeling and Analysis (PRIMA; Kraucunas et al., 2014). Implementation of VIC-CropSyst in EaSMs facilitates a powerful representation of large-scale interactions between different biophysical and socioeconomic components over areas with significant agricultural activities. This is a transformational step in the understanding of the food-energy-water nexus which can lead to efficient and more sustainable management decisions that balance and benefit all three sectors.

Code and data availability. The VIC-CropSyst is a freeware opensource community model; source codes, user manual, and test cases can be distributed by request to Keyvan Malek (keyvan.malek@wsu.edu), Jennifer Adam (jcadam@wsu.edu), and Mingliang Liu (mingliang.liu@wsu.edu). 


\section{Appendix A: Nomenclature}

$\begin{array}{ll}A_{\mathrm{w}} & \text { Soil wetted area } \\ b_{\mathrm{i}} & \text { Runoff calibration parameter } \\ D & \text { Droplet size } \\ D_{\mathrm{p}} & \text { Deep percolation } \\ D_{\mathrm{S}} & \text { VIC base flow calibration parameter } \\ D_{\mathrm{smax}} & \text { VIC base flow calibration parameter } \\ E_{\mathrm{c}} & \text { Evaporation of irrigation water intercepted by the crop canopy } \\ E_{\mathrm{d}} & \text { Evaporation from irrigation droplets } \\ E_{\mathrm{S}} & \text { Evaporation from soil } \\ E_{\mathrm{si}} & \text { Evaporation from soil during irrigation } \\ \text { ET } & \text { Potential evapotranspiration } \\ g & \text { Acceleration of gravity } \\ \mathrm{GDD} & \text { Growing degree day } \\ K_{\mathrm{c}} & \text { Crop coefficient } \\ K_{\mathrm{S}} & \text { Saturated hydraulic conductivity } \\ \text { LAI } & \text { Leaf area index } \\ \mathrm{MAD} & \text { Maximum allowable depletion } \\ q & \text { Drip irrigation emitter discharge rate } \\ R_{\mathrm{O}} & \text { Runoff loss } \\ S & \text { Sorptivity coefficient } \\ T & \text { Transpiration } \\ T_{\mathrm{i}} & \text { Time of irrigation } \\ V_{0} & \text { Initial velocity of droplets } \\ W_{\mathrm{s}} & \text { VIC base flow calibration parameter } \\ Y & \text { Canopy height } \\ Y_{0} & \text { Height of nozzle } \\ & \\ & \end{array}$


Competing interests. The authors declare that they have no conflict of interest.

Acknowledgements. We would like to thank three anonymous reviewers for their constructive comments and suggestions. We would also like to thank the editor Chritopher Müller for his insightful comments and valuable suggestions. This research was funded by Washington State Department of Ecology's Office of Columbia River Basin and the US Department of Agriculture's National Institute of Food and Agriculture, grant number 201167003-30346 (Biosphere-relevant Earth System Model; BioEarth). This research is also financially supported by Washington State University's Graduate School.

Edited by: Christoph Müller

Reviewed by: three anonymous referees

\section{References}

Abatzoglou, J. T. and Brown, T. J.: A comparison of statistical downscaling methods suited for wildfire applications, Int. J. Climatol., 32, 772-780, https://doi.org/10.1002/joc.2312, 2012.

Adam, J. C., Haddeland, I., Su, F., and Lettenmaier, D. P.: Simulation of reservoir influences on annual and seasonal streamflow changes for the Lena, Yenisei, and Ob' rivers, J. Geophys. Res.Atmos., 112, D2411, https://doi.org/10.1029/2007JD008525, 2007.

Adam, J. C., Hamlet, A. F., and Lettenmaier, D. P.: Implications of global climate change for snowmelt hydrology in the twenty-first century, Hydrol. Process., 23, 962-972, https://doi.org/10.1002/hyp.7201, 2009.

Adam, J. C., Stephens, J. C., Chung, S. H., Brady, M. P., Evans, R. D., Kruger, C. E., Lamb, B. K., Liu, M., Stöckle, C. O., Vaughan, J. K., Rajagopalan, K., Harrison, J. A., Tague, C. L., Kalyanaraman, A., Chen, Y., Guenther, A., Leung, F.-Y., Leung, L. R., Perleberg, A. B., Yoder, J., Allen, E., Anderson, S., Chandrasekharan, B., Malek, K., Mullis, T., Miller, C., Nergui, T., Poinsatte, J., Reyes, J., Zhu, J., Choate, J. S., Jiang, X., Nelson, R., Yoon, J.H., Yorgey, G. G., Johnson, K., Chinnayakanahalli, K. J., Hamlet, A. F., Nijssen, B., and Walden, V.: BioEarth: Envisioning and developing a new regional earth system model to inform natural and agricultural resource management, Climatic Change, 129, 555571, https://doi.org/10.1007/s10584-014-1115-2, 2014.

Adamson, D. and Loch, A.,: Possible negative feedbacks from 'gold-plating' irrigation infrastructure. Exploring some of the socio-economic realities of sustainable water management in irrigation, Agric. Water Manage., 145, 134-144, https://doi.org/10.1016/j.agwat.2013.09.022, 2014.

Ainsworth, E. A. and Rogers, A.: The response of photosynthesis and stomatal conductance to rising $\left[\mathrm{CO}_{2}\right]$ : mechanisms and environmental interactions, Plant Cell Environ., 30, 258-270, https://doi.org/10.1111/j.1365-3040.2007.01641.x, 2007.

Allen, E., Forney, W., Harrison, J., Kruger, C., Saari, B., Stephens, J., and Yorgey, G.: BioEarth Water Quality Stakeholder Advisory Workshop Synthesis Report, Washington State University, Groups not represented at the stakeholder workshop, but recommended for future inclusion by attending stakeholders: USDA
Natural Resources Conservation Service and Agricultural Research Service, tribal governments, 2015.

Allen, R. G.: Crop evapotranspiration - Guidelines for computing crop water requirements, FAO Irrigation and drainage paper 56, FAO, Rome, 1998.

Alva, A. K., Marcos, J., Stockle, C., Reddy, V. R., and Timlin, D.: A Crop Simulation Model for Predicting Yield and Fate of Nitrogen in Irrigated Potato Rotation Cropping System, J. Crop Improv., 24, 142-152, https://doi.org/10.1080/15427520903581239, 2010.

Andreadis, K. M., Storck, P., and Lettenmaier, D. P.: Modeling snow accumulation and ablation processes in forested environments, Water Resour. Res., 45, W05429, https://doi.org/10.1029/2008WR007042, 2009.

Anwar, M. R., Liu, D. L., Macadam, I., and Kelly, G.: Adapting agriculture to climate change: a review, Theor. Appl. Climatol., 113, 225-245, https://doi.org/10.1007/s00704-012-0780-1, 2013.

Arnold, J. G., Srinivasan, R., Muttiah, R. S., and Williams, J. R.: Large Area Hydrologic Modeling and Assessment Part I: Model Development 1, J. Am. Water Resour. Assoc., 34, 73-89, https://doi.org/10.1111/j.1752-1688.1998.tb05961.x, 1998.

Baker, I. T., Prihodko, L., Denning, A. S., Goulden, M., Miller, S., and da Rocha, H. R.: Seasonal drought stress in the Amazon: Reconciling models and observations, J. Geophys. Res.-Biogeo., 113, G00B01, https://doi.org/10.1029/2007JG000644, 2008.

Baldocchi, D., Falge, E., Gu, L., Olson, R., Hollinger, D., Running, S., Anthoni, P., Bernhofer, C., Davis, K., Evans, R., and Fuentes, J.: FLUXNET: A new tool to study the temporal and spatial variability of ecosystem-scale carbon dioxide, water vapor, and energy flux densities, B. Am. Meteorol. Soc., 82, 2415-2434, 2001.

Barik, M., Adam, J., Yoder, J., Haller, D., Barber, M. E., Hall, S. A., Kruger, C. E., Yorgey, G. G., Downes, M., Stockle, C., Aryal, B., Carlson, T., Damiano, G., Dhungel, S., Einberger, C., Hamel-Reiken, K., Liu, M., Malek, K., McClure, S., Nelson, R., O’Brien, M., Padowski, J., Rajagopalan, K., and Valdez, W.: 2016 Technical Supplement for the Columbia River Basin Long-Term Water Supply and Demand Forecast, Publication No. 16-12-008, Washington Department of Ecology, Olympia, WA, 2017.

Barnett, T. P., Adam, J. C., and Lettenmaier, D. P.: Potential impacts of a warming climate on water availability in snow-dominated regions, Nature, 438, 303-309, https://doi.org/10.1038/nature04141, 2005.

Barnston, A. G. and Schickedanz, P. T.: The Effect of Irrigation on Warm Season Precipitation in the Southern Great Plains, J. Clim. Appl. Meteorol., 23, 865-888, https://doi.org/10.1175/15200450(1984)023<0865:TEOIOW>2.0.CO;2, 1984.

Berger, T. and Troost, C.: Agent-based Modelling of Climate Adaptation and Mitigation Options in Agriculture, J. Agric. Econ., 65, 323-348, https://doi.org/10.1111/1477-9552.12045, 2014.

Best, M. J., Pryor, M., Clark, D. B., Rooney, G. G., Essery, R. L. H., Ménard, C. B., Edwards, J. M., Hendry, M. A., Porson, A., Gedney, N., Mercado, L. M., Sitch, S., Blyth, E., Boucher, O., Cox, P. M., Grimmond, C. S. B., and Harding, R. J.: The Joint UK Land Environment Simulator (JULES), model description Part 1: Energy and water fluxes, Geosci. Model Dev., 4, 677-699, https://doi.org/10.5194/gmd-4-677-2011, 2011. 
Biemans, H., Haddeland, I., Kabat, P., Ludwig, F., Hutjes, R. W. A., Heinke, J., von Bloh, W., and Gerten, D.: Impact of reservoirs on river discharge and irrigation water supply during the 20th century, Water Resour. Res., 47, W03509, https://doi.org/10.1029/2009WR008929, 2011.

Bierkens, M. F. P.: Global hydrology 2015: State, trends, and directions, Water Resour. Res., 51, 4923-4947, https://doi.org/10.1002/2015WR017173, 2015.

Boryan, C., Yang, Z., Mueller, R., and Craig, M.: Monitoring US agriculture: the US Department of Agriculture, National Agricultural Statistics Service, Cropland Data Layer Program, Geocarto Int., 26, 341-358, https://doi.org/10.1080/10106049.2011.562309, 2011.

Campbell, G. S.: A simple method for determining unsaturated conductivity from moisture retention data, Soil Sci., 117, 311-314, 1974.

Causapé, J., Quílez, D., and Aragüés, R.: Irrigation Efficiency and Quality of Irrigation Return Flows in the Ebro River Basin: An Overview, Environ. Monit. Assess., 117, 451-461, https://doi.org/10.1007/s10661-006-0763-8, 2004.

Chang, K.-H., Warland, J. S., Bartlett, P. A., Arain, A. M., and Yuan, F.: A Simple Crop Phenology Algorithm in the Land Surface Model CN-CLASS, Agron. J., 106, 297-308, https://doi.org/10.2134/agronj2013.0164, 2014.

Chen, M., Griffis, T. J., Baker, J., Wood, J. D., and Xiao, K.: Simulating crop phenology in the Community Land Model and its impact on energy and carbon fluxes, J. Geophys. Res.-Biogeo., 120, 310-325, https://doi.org/10.1002/2014JG002780, 2015.

Cherkauer, K. A., Bowling, L. C., and Lettenmaier, D. P.: Variable infiltration capacity cold land process model updates, Global Planet. Change, 38, 151-159, https://doi.org/10.1016/S09218181(03)00025-0, 2003.

Cohen, W. B., Maiersperger, T. K., Turner, D. P., Ritts, W. D., Pflugmacher, D., Kennedy, R. E., Kirschbaum, A., Running, S. W., Costa, M., and Gower, S. T.: MODIS land cover and LAI collection 4 product quality across nine sites in the western hemisphere, IEEE T. Geosci. Remote, 44, 1843-1857, https://doi.org/10.1109/TGRS.2006.876026, 2006.

Confalonieri, R. and Bocchi, S.: Evaluation of CropSyst for simulating the yield of flooded rice in northern Italy, Eur. J. Agron., 23, 315-326, https://doi.org/10.1016/j.eja.2004.12.002, 2005.

Cosens, B.: Transboundary river governance in the face of uncertainty: resilience theory and the Columbia River Treaty, J. Land Resour. Envtl., 30, 229, 2010.

Crow, W. T., Berg, A. A., Cosh, M. H., Loew, A., Mohanty, B. P., Panciera, R., de Rosnay, P., Ryu, D., and Walker, J. P.: Upscaling sparse ground-based soil moisture observations for the validation of coarse-resolution satellite soil moisture products, Rev. Geophys., 50, RG2002, https://doi.org/10.1029/2011RG000372, 2012

Douglas, E. M., Beltrán-Przekurat, A., Niyogi, D., Pielke Sr., R. A., and Vörösmarty, C. J.: impact of agricultural intensification and irrigation on land-atmosphere interactions and Indian monsoon precipitation - A mesoscale modeling perspective, Changes in land use and water use and their consequences on climate, including biogeochemical cycles, Global Planet. Change, 67, 117-128, https://doi.org/10.1016/j.gloplacha.2008.12.007, 2009.

Drewniak, B., Song, J., Prell, J., Kotamarthi, V. R., and Jacob, R.: Modeling agriculture in the Community Land Model,
Geosci. Model Dev. 6, 495-515, https://doi.org/10.5194/gmd-6495-2013, 2013.

Dukes, J. S. and Mooney, H. A.: Does global change increase the success of biological invaders?, Trends Ecol. Evol., 14, 135-139, https://doi.org/10.1016/S0169-5347(98)01554-7, 1999.

Elliott, J., Deryng, D., Müller, C., Frieler, K., Konzmann, M., Gerten, D., Glotter, M., Flörke, M., Wada, Y., Best, N., Eisner, S., Fekete, B. M., Folberth, C., Foster, I., Gosling, S. N., Haddeland, I., Khabarov, N., Ludwig, F., Masaki, Y., Olin, S., Rosenzweig, C., Ruane, A. C., Satoh, Y., Schmid, E., Stacke, T., Tang, Q., and Wisser, D.: Constraints and potentials of future irrigation water availability on agricultural production under climate change, P. Natl. Acad. Sci. USA, 111, 3239-3244, https://doi.org/10.1073/pnas.1222474110, 2014.

Elsner, M. M., Cuo, L., Voisin, N., Deems, J. S., Hamlet, A. F., Vano, J. A., Mickelson, K. E. B., Lee, S.-Y., and Lettenmaier, D. P.: Implications of 21 st century climate change for the hydrology of Washington State, Climatic Change, 102, 225-260, https://doi.org/10.1007/s10584-010-9855-0, 2010.

FAO and WFP: The state of food insecurity in the world 2013, Mult. Dimens. Food Secur., FAO, Rome, 2013.

Ferguson, I. M. and Maxwell, R. M.: Hydrologic and landenergy feedbacks of agricultural water management practices, Environ. Res. Lett., 6, 014006, https://doi.org/10.1088/17489326/6/1/014006, 2011.

Fernández, J. E., Palomo, M. J., Díaz-Espejo, A., Clothier, B. E., Green, S. R., Girón, I. F., and Moreno, F.: Heat-pulse measurements of sap flow in olives for automating irrigation: tests, root flow and diagnostics of water stress, Agric. Water Manage., 51, 99-123, https://doi.org/10.1016/S0378-3774(01)00119-6, 2001.

Ferrer, F., Villar, J. M., and Stockle, C. O.: Evaluation of CropSyst, a cropping systems simulation model, for irrigated corn in the Ebro Valley, Investig. Agrar. Prod. Protección Veg., 15, 237-251, 2000.

Fisher, R. A., Muszala, S., Verteinstein, M., Lawrence, P., Xu, C., McDowell, N. G., Knox, R. G., Koven, C., Holm, J., Rogers, B. M., Spessa, A., Lawrence, D., and Bonan, G.: Taking off the training wheels: the properties of a dynamic vegetation model without climate envelopes, CLM4.5 (ED), Geosci. Model Dev., 8, 3593-3619, https://doi.org/10.5194/gmd-8-3593-2015, 2015.

Franchini, M. and Pacciani, M.: Comparative analysis of several conceptual rainfall-runoff models, J. Hydrol., 122, 161-219, https://doi.org/10.1016/0022-1694(91)90178-K, 1991.

Frank, J. M., Massman, W. J., and Ewers, B. E.: Underestimates of sensible heat flux due to vertical velocity measurement errors in non-orthogonal sonic anemometers, Agr. Forest Meteorol., 171172, 72-81, https://doi.org/10.1016/j.agrformet.2012.11.005, 2013.

García-Gaines, R. A. and Frankenstein, S.: USCS and the USDA Soil Classification System: Development of a Mapping Scheme, DTIC Document, Cold regions research and engineering lab, Engineer research and development center, Hanover, NH, 2015.

Godfray, H. C. J., Beddington, J. R., Crute, I. R., Haddad, L., Lawrence, D., Muir, J. F., Pretty, J., Robinson, S., Thomas, S. M., and Toulmin, C.: Food Security: The Challenge of Feeding 9 Billion People, Science, 327, 812-818, https://doi.org/10.1126/science.1185383, 2010.

Gordon, L. J., Peterson, G. D., and Bennett, E. M.: Agricultural modifications of hydrological flows create eco- 
logical surprises, Trends Ecol. Evol., 23, 211-219, https://doi.org/10.1016/j.tree.2007.11.011, 2008.

Gosain, A. K., Rao, S., Srinivasan, R., and Reddy, N. G.: Returnflow assessment for irrigation command in the Palleru river basin using SWAT model, Hydrol. Process., 19, 673-682., https://doi.org/10.1002/hyp.5622, 2005

Gosling, S. N. and Arnell, N. W.: Simulating current global river runoff with a global hydrological model: model revisions, validation, and sensitivity analysis, Hydrol. Process., 25, 1129-1145, https://doi.org/10.1002/hyp.7727, 2011.

Haddeland, I., Lettenmaier, D. P., and Skaugen, T.: Effects of irrigation on the water and energy balances of the Colorado and Mekong river basins, J. Hydrol., 324, 210-223, https://doi.org/10.1016/j.jhydrol.2005.09.028, 2006.

Haddeland, I., Heinke, J., Biemans, H., Eisner, S., Flörke, M., Hanasaki, N., Konzmann, M., Ludwig, F., Masaki, Y., Schewe, J., Stacke, T., Tessler, Z. D., Wada, Y., and Wisser, D.: Global water resources affected by human interventions and climate change, P. Natl. Acad. Sci. USA, 111, 3251-3256, https://doi.org/10.1073/pnas.1222475110, 2014

Hall, S. A., Adam, J., Barik, M., Yoder, J., Brday, M. P., Haller, D., Barber, M. E., Kruger, C. E., Yorgey, G. G., Downes, M., Stockle, C., Aryal, B., Carlson, T., Damiano, G., Dhungel, S., Einberger, C., Hamel-Reiken, K., Liu, M., Malek, K., McClure, S., Nelson, R., O'Brien, M., Padowski, J., Rajagopalan, K., and Valdez, W.: 2016 Washington State Legislative Report, Columbia River Basin Long-Term Water Supply and Demand Forecast, No. 16-12-001, Washington Department of Ecology, Olympia, WA, 2017

Hamlet, A. F. and Lettenmaier, D. P.: Effects of Climate Change on Hydrology and Water Resources in the Columbia River Basin1, J. Am. Water Resour. Assoc., 35, 1597-1623, https://doi.org/10.1111/j.1752-1688.1999.tb04240.x, 1999.

Hanasaki, N., Inuzuka, T., Kanae, S., and Oki, T.: An estimation of global virtual water flow and sources of water withdrawal for major crops and livestock products using a global hydrological model, J. Hydrol., 384, 232-244, https://doi.org/10.1016/j.jhydrol.2009.09.028, 2010.

Hansen, J., Challinor, A., Ines, A., Wheeler, T., and Moron, V.: Translating climate forecasts into agricultural terms: advances and challenges, Clim. Res., 33, 27-41, https://doi.org/10.3354/cr033027, 2006.

Harding, K. J., Twine, T. E., and Lu, Y.: Effects of Dynamic Crop Growth on the Simulated Precipitation Response to Irrigation, Earth Interact., 19, 1-31, https://doi.org/10.1175/EI-D-15$0030.1,2015$.

Howden, S. M., Soussana, J.-F., Tubiello, F. N., Chhetri, N., Dunlop, M., and Meinke, H.: Adapting agriculture to climate change, P. Natl. Acad. Sci. USA, 104, 19691-19696, https://doi.org/10.1073/pnas.0701890104, 2007.

Hubble, J. D.: Yakima River Basin Integrated Water Resource Management Plan: Final Programmatic Environmental Impact Statement, Fish Benefits Analysis Technical Memorandum, US Bureau of Reclamation, 2012.

Jägermeyr, J., Gerten, D., Heinke, J., Schaphoff, S., Kummu, M., and Lucht, W.: Water savings potentials of irrigation systems: global simulation of processes and linkages, Hydrol. Earth Syst. Sci., 19, 3073-3091, https://doi.org/10.5194/hess-19-3073-2015, 2015.
Jalota, S. K., Singh, S., Chahal, G. B. S., Ray, S. S., Panigraghy, S., and Bhupinder-Singh, K. B.: Soil texture, climate and management effects on plant growth, grain yield and water use by rainfed maize-wheat cropping system: Field and simulation study, Agric. Water Manage., 97, 83-90, https://doi.org/10.1016/j.agwat.2009.08.012, 2010.

Jones, J. W., Hoogenboom, G., Porter, C. H., Boote, K. J., Batchelor, W. D., Hunt, L. A., Wilkens, P. W., Singh, U., Gijsman, A. J., and Ritchie, J. T.: The DSSAT cropping system model, Modelling Cropping Systems: Science, Software and Applications, Eur. J. Agron., 18, 235-265, https://doi.org/10.1016/S11610301(02)00107-7, 2003.

Kang, Y., Wang, Q.-G., and Liu, H.-J.: Winter wheat canopy interception and its influence factors under sprinkler irrigation, Agric. Water Manage., 74, 189-199, https://doi.org/10.1016/j.agwat.2004.11.004, 2005.

Karimi, T., Stockle, C. O., Higgins, S. S., and Nelson, R. L.: Projected Dryland Cropping System Shifts in the Pacific Northwest in Response to Climate Change, Front. Ecol. Evol, 5, 20, https://doi.org/10.3389/fevo.2017.00020, 2017.

Klein, T., Calanca, P., Holzkämper, A., Lehmann, N., Roesch, A., and Fuhrer, J.: Using farm accountancy data to calibrate a crop model for climate impact studies, Agric. Syst., 111, 23-33, https://doi.org/10.1016/j.agsy.2012.05.001, 2012.

Kohl, R. A. and Wright, J. L.: Air Temperature and Vapor Pressure Changes Caused by Sprinkler Irrigation, Agron. J., 66, 85-88, https://doi.org/10.2134/agronj1974.00021962006600010024x, 1974.

Kraucunas, I., Clarke, L., Dirks, J., Hathaway, J., Hejazi, M., Hibbard, K., Huang, M., Jin, C., Kintner-Meyer, M., van Dam, K. K., Leung, R., Li, H.-Y., Moss, R., Peterson, M., Rice, J., Scott, M., Thomson, A., Voisin, N., and West, T.: Investigating the nexus of climate, energy, water, and land at decisionrelevant scales: the Platform for Regional Integrated Modeling and Analysis (PRIMA), Climatic Changem 129, 573-588, https://doi.org/10.1007/s10584-014-1064-9, 2014.

Kurukulasuriya, P. and Rosenthal, S.: Climate change and agriculture: a review of impacts and adaptations, Environment department papers no. 91, Climate change series, World Bank, Washington, D.C., available at: https://openknowledge.worldbank. org/handle/10986/16616License:CCBY3.0IGO (last access: August 2017), 2003.

Leakey, A. D. B., Ainsworth, E. A., Bernacchi, C. J., Rogers, A., Long, S. P., and Ort, D. R.: Elevated $\mathrm{CO}_{2}$ effects on plant carbon, nitrogen, and water relations: six important lessons from FACE, J. Exp. Bot., 60, 2859-2876, https://doi.org/10.1093/jxb/erp096, 2009.

Leng, G., Huang, M., Tang, Q., Sacks, W. J., Lei, H., and Leung, L. R.: Modeling the effects of irrigation on land surface fluxes and states over the conterminous United States: Sensitivity to input data and model parameters, J. Geophys. Res.-Atmos., 118, 9789 9803, https://doi.org/10.1002/jgrd.50792, 2013.

Leuning, R., van Gorsel, E., Massman, W. J., and Isaac, P. R.: Reflections on the surface energy imbalance problem, Agr. Forest Meteorol., 156, 65-74, https://doi.org/10.1016/j.agrformet.2011.12.002, 2012.

Liang, X., Lettenmaier, D. P., Wood, E. F., and Burges, S. J.: A simple hydrologically based model of land surface water and energy 
fluxes for general circulation models, J. Geophys. Res.-Atmos., 99, 14415-14428, https://doi.org/10.1029/94JD00483, 1994.

Liang, X., Lettenmaier, D. P., and Wood, E. F.: One-dimensional statistical dynamic representation of subgrid spatial variability of precipitation in the two-layer variable infiltration capacity model, J. Geophys. Res. Atmos., 101, 21403-21422, https://doi.org/10.1029/96JD01448, 1996.

Liu, H.-J. and Kang, Y.: Effect of sprinkler irrigation on microclimate in the winter wheat field in the North China Plain, Agric. Water Manage., 84, 3-19, https://doi.org/10.1016/j.agwat.2006.01.015, 2006.

Liu, M., Adam, J. C., and Hamlet, A. F.: Spatial-temporal variations of evapotranspiration and runoff/precipitation ratios responding to the changing climate in the Pacific Northwest during 19212006: Trends in ET and R/P across the PNW, J. Geophys. Res.Atmos., 118, 380-394, https://doi.org/10.1029/2012JD018400, 2013

Liu, X., Chen, F., Barlage, M., Zhou, G., and Niyogi, D.: Noah-MPCrop: Introducing dynamic crop growth in the Noah-MP land surface model, J. Geophys. Res.-Atmos., 121, 2016JD025597, https://doi.org/10.1002/2016JD025597, 2016.

Lobell, D., Bala, G., Mirin, A., Phillips, T., Maxwell, R., and Rotman, D.: Regional Differences in the Influence of Irrigation on Climate, J. Climate, 22, 2248-2255, https://doi.org/10.1175/2008JCLI2703.1, 2009.

Lobell, D. B., Bonfils, C. J., Kueppers, L. M., and Snyder, M. A.: Irrigation cooling effect on temperature and heat index extremes. Geophys. Res. Lett., 35, L09705, https://doi.org/10.1029/2008GL034145, 2008.

Lohmann, D., Raschke, E., Nijssen, B., and Lettenmaier, D. P.: Regional scale hydrology: I. Formulation of the VIC-2L model coupled to a routing model, Hydrolog. Sci. J., 43, 131-141, https://doi.org/10.1080/02626669809492107, 1998.

Long, S. P. and Ort, D. R.: More than taking the heat: crops and global change, Curr. Opin. Plant Biol., 13, 240-247, https://doi.org/10.1016/j.pbi.2010.04.008, 2010.

Long, S. P., Marshall-Colon, A., and Zhu, X.-G.: Meeting the Global Food Demand of the Future by Engineering Crop Photosynthesis and Yield Potential, Cell, 161, 56-66, https://doi.org/10.1016/j.cell.2015.03.019, 2015.

Lu, Y., Jin, J., and Kueppers, L. M.: Crop growth and irrigation interact to influence surface fluxes in a regional climate-cropland model (WRF3.3-CLM4crop), Clim. Dynam., 45, 3347-3363, https://doi.org/10.1007/s00382-015-2543-z, 2015.

Mahrt, L.: Flux Sampling Errors for Aircraft and Towers, J. Atmos. Ocean. Tech., 15, 416-429, https://doi.org/10.1175/15200426(1998)015<0416:FSEFAA>2.0.CO;2, 1998.

Malek, K. and Peters, R.: Wetting Pattern Models for Drip Irrigation: New Empirical Model, J. Irrig. Drain. Eng., 137, 530-536, https://doi.org/10.1061/(ASCE)IR.1943-4774.0000320, 2011.

Malek, K., Stockle, C., Adam, J., and Peters, T.: Climate change reduces water availability for agriculture by decreasing nonevaporative irrigation losses, in review, 2017a.

Malek, K., Adam, J. C., Stockle, C. O., Brady, M., and Rajagopalan, K.: When should irrigators invest in more water-efficient technologies as an adaptation to climate change?, in preparation, $2017 b$.

Maurer, E. P., Wood, A. W., Adam, J. C., Lettenmaier, D. P., and Nijssen, B.: A Long-Term Hydrologically Based Dataset of
Land Surface Fluxes and States for the Conterminous United States. J. Climate, 15, 3237-3251, https://doi.org/10.1175/15200442(2002)015<3237:ALTHBD>2.0.CO;2, 2002.

McMaster, G. S. and Wilhelm, W. W.: Growing degree-days: one equation, two interpretations, Agr. Forest Meteorol., 87, 291300, https://doi.org/10.1016/S0168-1923(97)00027-0, 1997.

Michalakes, J., Dudhia, J., Gill, D., Henderson, T., Klemp, J., Skamarock, W., and Wang, W.: The weather research and forecast model: software architecture and performance, in: Proceedings of the 11th ECMWF Workshop on the Use of High Performance Computing in Meteorology, World Scientific, Singapore,, 156$168,2005$.

Milly, P. C. D., Malyshev, S. L., Shevliakova, E., Dunne, K. A., Findell, K. L., Gleeson, T., Liang, Z., Phillipps, P., Stouffer, R. J., and Swenson, S.: An Enhanced Model of Land Water and Energy for Global Hydrologic and Earth-System Studies, J. Hydrometeorol., 15, 1739-1761, https://doi.org/10.1175/JHMD-13-0162.1, 2014.

Mitchell, K. E., Lohmann, D., Houser, P. R., Wood, E. F., Schaake, J. C., Robock, A., Cosgrove, B. A., Sheffield, J., Duan, Q., Luo, L., Higgins, R. W., Pinker, R. T., Tarpley, J. D., Lettenmaier, D. P., Marshall, C. H., Entin, J. K., Pan, M., Shi, W., Koren, V., Meng, J., Ramsay, B. H., and Bailey, A. A.: The multi-institution North American Land Data Assimilation System (NLDAS): Utilizing multiple GCIP products and partners in a continental distributed hydrological modeling system, J. Geophys. Res.Atmos., 109, D07S90, https://doi.org/10.1029/2003JD003823, 2004.

Mote, P. W., Hamlet, A. F., Clark, M. P., and Lettenmaier, D. P.: Declining mountain snowpack in western North America, B. Am. Meteorol. Soc., 86, 39-49, https://doi.org/10.1175/BAMS-86-139, 2005.

Nafziger, E.: Illinois Agronomy Handbook now online - ACES News: College of ACES, University of Illinois, available at" http://news.aces.illinois.edu/news/ illinois-agronomy-handbook-now-online (last access: 1 February 2016), 2013.

Neitsch, S. L., Arnold, J. G., Kiniry, J. R., and Williams, J. R.: Soil and water assessment tool theoretical documentation version 2009, Texas Water Resources Institute, 2011.

Nelson Co.: Product information and documentation, http://www. nelsonirrigation.com/resources/, last access: 19 June 2014.

Nijs, I., Ferris, R., Blum, H., Hendrey, G., and Impens, I.: Stomatal regulation in a changing climate: a field study using Free Air Temperature Increase (FATI) and Free Air $\mathrm{CO}_{2}$ Enrichment (FACE), Plant Cell Environ., 20, 1041-1050, https://doi.org/10.1111/j.1365-3040.1997.tb00680.x, 1997.

Ozdogan, M., Rodell, M., Beaudoing, H. K., and Toll, D. L.: Simulating the Effects of Irrigation over the United States in a Land Surface Model Based on SatelliteDerived Agricultural Data, J. Hydrometeorol., 11, 171-184, https://doi.org/10.1175/2009JHM1116.1, 2010.

Pachepsky, Y. A. and Rawls, W. J.: Accuracy and Reliability of Pedotransfer Functions as Affected by Grouping Soils, Soil Sci. Soc. Am. J., 63, 1748-1757, https://doi.org/10.2136/sssaj1999.6361748x, 1999.

Pala, M., Stockle, C. O., and Harris, H. C.: Simulation of durum wheat (Triticum turgidum ssp. durum) growth under different water and nitrogen regimes in a mediter- 
ranean environment using CropSyst, Agric. Syst., 51, 147-163, https://doi.org/10.1016/0308-521X(95)00043-5, 1996.

Pannkuk, C. D., Stockle, C. O., and Papendick, R. I.: Evaluating CropSyst simulations of wheat management in a wheat-fallow region of the US pacific northwest, Agric. Syst., 57, 121-134, https://doi.org/10.1016/S0308-521X(97)00076-0, 1998.

Parry, M., Rosenzweig, C., and Livermore, M.: Climate change, global food supply and risk of hunger, Philos. T. Roy. Soc. B, 360, 2125-2138, https://doi.org/10.1098/rstb.2005.1751, 2005.

Philip, J. R.: The Theory of Infiltration, available at: http:// journals.lww.com/soilsci/Fulltext/1957/05000/THE_THEORY_ OF_INFILTRATION_1_THE_INFILTRATION.2.aspx (last access: 20 October 2014), 1957.

Pielke Sr., R. A., Adegoke, J. O., Chase, T. N., Marshall, C. H., Matsui, T., and Niyogi, D.: A new paradigm for assessing the role of agriculture in the climate system and in climate change, The Contribution of Agriculture to the State of Climate, Agr. Forest Meteorol., 142, 234-254, https://doi.org/10.1016/j.agrformet.2006.06.012, 2007.

Playán, E., Salvador, R., Faci, J. M., Zapata, N., Martínez-Cob, A., and Sánchez, I.: Day and night wind drift and evaporation losses in sprinkler solid-sets and moving laterals, Agric. Water Manage., 76, 139-159, https://doi.org/10.1016/j.agwat.2005.01.015, 2005.

Pokhrel, Y. N., Hanasaki, N., Koirala, S., Cho, J., Yeh, P. J.-F., Kim, H., Kanae, S., and Oki, T.: Incorporating Anthropogenic Water Regulation Modules into a Land Surface Model, J. Hydrometeorol., 13, 255-269, https://doi.org/10.1175/JHM-D-11-013.1, 2011.

Pokhrel, Y. N., Hanasaki, N., Wada, Y., and Kim, H.: Recent progresses in incorporating human land-water management into global land surface models toward their integration into Earth system models, Wiley Interdiscip. Rev. Water, 3, 548-574, https://doi.org/10.1002/wat2.1150, 2016.

Puma, M. J. and Cook, B. I.: Effects of irrigation on global climate during the 20th century, J. Geophys. Res.-Atmos., 115, D16120, https://doi.org/10.1029/2010JD014122, 2010.

RainBird: Master Part Book: Rain Bird Manuals, Product Literature, Performance Data \& Replacement Parts for Agriculture Irrigation Systems, Rain Bird Corporation, Azusa, CA, 2014.

Rajagopalan, K., Chinnayakanahalli, K. J., Stockle, C., Nelson, R., Hamlet, A. F., Brady, M. P., Barber, M. E., Kruger, C., Yorgey, G. G., Malek, K., Dinesh, S., and Adam, J.: Impacts of regional climate change on agricultural production in the Columbia River Basin, in review, 2017.

Rawls, W. J., Ahuja, L. R., Brakensiek, D. L., and Shirmohammadi, A.: Infiltration and soil water movement, in: Handbook of hydrology, McGraw-Hil, New York, 1-51, 1992.

Robertson, G. P. and Swinton, S. M.: Reconciling agricultural productivity and environmental integrity: a grand challenge for agriculture, Front. Ecol. Environ., 3, 38-46, https://doi.org/10.1890/15409295(2005)003[0038:RAPAEI]2.0.CO;2, 2005.

Robinson, D. A., Campbell, C. S., Hopmans, J. W., Hornbuckle, B. K., Jones, S. B., Knight, R., Ogden, F., Selker, J., and Wendroth, O.: Soil Moisture Measurement for Ecological and Hydrological Watershed-Scale Observatories: A Review, Vadose Zone J., 7, 358-389, https://doi.org/10.2136/vzj2007.0143, 2008.
Rosenzweig, C., Iglesias, A., Yang, X. B., Epstein, P. R., and Chivian, E.: Climate Change and Extreme Weather Events; Implications for Food Production, Plant Diseases, and Pests, Global Change Hum. Health, 2, 90-104, https://doi.org/10.1023/A:1015086831467, 2001.

Rost, S., Gerten, D., Bondeau, A., Lucht, W., Rohwer, J., and Schaphoff, S.: Agricultural green and blue water consumption and its influence on the global water system, Water Resour. Res., 44, W09405, https://doi.org/10.1029/2007WR006331, 2008.

Rowan, T. S. C., Maier, H. R., Connor, J., and Dandy, G. C.: An integrated dynamic modeling framework for investigating the impact of climate change and variability on irrigated agriculture, Water Resour. Res., 47, W07520, https://doi.org/10.1029/2010WR010195, 2011.

Rushi, B. R., Barik, M. G., Lee, S. Y., Rajagopalan, K., Petrie, J., Barber, M. E., Boll, J., and Adam, J. C.: Columbia River Treaty Renegotiation: Potential Impacts on Agriculture, Hydropower and Flood Risk in the Context of an Altered Climate, AGU Fall Meet. Abstr., 43, 2016.

Sakamoto, T., Wardlow, B. D., Gitelson, A. A., Verma, S. B., Suyker, A. E., and Arkebauer, T. J.: A Two-Step Filtering approach for detecting maize and soybean phenology with timeseries MODIS data, Remote Sens. Environ., 114, 2146-2159, https://doi.org/10.1016/j.rse.2010.04.019, 2010.

Saxton, K. E., Rawls, W. J., Romberger, J. S., and Papendick, R. I.: Estimating Generalized Soil-water Characteristics from Texture, Soil Sci. Soc. Am. J., 50, 1031, https://doi.org/10.2136/sssaj1986.03615995005000040039x, 1986.

Scanlon, B. R., Jolly, I., Sophocleous, M., and Zhang, L.: Global impacts of conversions from natural to agricultural ecosystems on water resources: Quantity versus quality, Water Resour. Res., 43, W03437, https://doi.org/10.1029/2006WR005486, 2007.

Schwalm, C. R., Williams, C. A., Schaefer, K., Anderson, R., Arain, M. A., Baker, I., Barr, A., Black, T. A., Chen, G., Chen, J. M., Ciais, P., Davis, K. J., Desai, A., Dietze, M., Dragoni, D., Fischer, M. L., Flanagan, L. B., Grant, R., Gu, L., Hollinger, D., Izaurralde, R. C., Kucharik, C., Lafleur, P., Law, B. E., Li, L., Li, Z., Liu, S., Lokupitiya, E., Luo, Y., Ma, S., Margolis, H., Matamala, R., McCaughey, H., Monson, R. K., Oechel, W. C., Peng, C., Poulter, B., Price, D. T., Riciutto, D. M., Riley, W., Sahoo, A. K., Sprintsin, M., Sun, J., Tian, H., Tonitto, C., Verbeeck, H., and Verma, S. B.: A model-data intercomparison of $\mathrm{CO}_{2}$ exchange across North America: Results from the North American Carbon Program site synthesis, J. Geophys. Res.-Biogeo., 115, G00H05, https://doi.org/10.1029/2009JG001229, 2010.

Schwarz, G. E. and Alexander, R. B.: State Soil Geographic (STATSGO) Data Base for the Conterminous United States, Open-File Rep., available at: https://pubs.er.usgs.gov/ publication/ofr95449 (last access: August 2017), 1995.

Skamarock, W. C., Klemp, J., Dudhia, J., Gill, D. O., Barker, D. M., Duda, M. G., Huang, X.-Y., Wang, W., and Powers, J.: A Description of the Advanced Research WRF Version 3, NCAR Technical Note NCAR/TN-475+STR, https://doi.org/10.5065/D68S4MVH, 2008.

Smit, B. and Skinner, M. W.: Adaptation options in agriculture to climate change: a typology, Mitig. Adapt. Strateg. Glob. Change, 7, 85-114, https://doi.org/10.1023/A:1015862228270, 2002. 
Smith, B., Burton, I., Klein, R. J. T., and Wandel, J.: An Anatomy of Adaptation to Climate Change and Variability, Climatic Change, 45, 223-251, https://doi.org/10.1023/A:1005661622966, 2000.

Sorooshian, S., Li, J., Hsu, K., and Gao, X.: Influence of irrigation schemes used in regional climate models on evapotranspiration estimation: Results and comparative studies from California's Central Valley agricultural regions, J. Geophys. Res.-Atmos., 117, D06107, https://doi.org/10.1029/2011JD016978, 2012.

Sridhar, V.: Tracking the Influence of Irrigation on Land Surface Fluxes and Boundary Layer Climatology, J. Contemp. Water Res. Educ., 152, 79-93, https://doi.org/10.1111/j.1936704X.2013.03170.x, 2013.

Stöckle, C. O., Williams, J. R., Rosenberg, N. J., and Jones, C. A.: A method for estimating the direct and climatic effects of rising atmospheric carbon dioxide on growth and yield of crops: Part I - Modification of the EPIC model for climate change analysis, Agric. Syst., 38, 225-238, https://doi.org/10.1016/0308521X(92)90067-X, 1992.

Stöckle, C. O., Martin, S. A., and Campbell, G. S.: CropSyst, a cropping systems simulation model: Water/nitrogen budgets and crop yield, Agric. Syst., 46, 335-359, https://doi.org/10.1016/0308521X(94)90006-2, 1994.

Stöckle, C. O., Donatelli, M., and Nelson, R.: CropSyst, a cropping systems simulation model, Eur. J. Agron., 18, 289-307, https://doi.org/10.1016/S1161-0301(02)00109-0, 2003.

Takata, K., Emori, S., and Watanabe, T.: Development of the minimal advanced treatments of surface interaction and runoff, Global Planet. Change, 38, 209-222, https://doi.org/10.1016/S0921-8181(03)00030-4, 2003.

Tao, F., Yokozawa, M., Hayashi, Y., and Lin, E.: Changes in agricultural water demands and soil moisture in China over the last half-century and their effects on agricultural production, Agr. Forest Meteorol., 118, 251-261, https://doi.org/10.1016/S01681923(03)00107-2, 2003.

Thompson, A. L., Gilley, J. R., and Norman, J. M.: A sprinkler water droplet evaporation and plant canopy model. II. Model application, T. ASAE, 36, 743-750, 1993.

Thornton, P., Thornton, M., Mayer, B., Wilhelmi, N., Wei, Y., and Cook, R.: DAYMET: Daily Surface Weather on a $1 \mathrm{~km}$ Grid for North America, 1980-2008, Oak Ridge Natl. Lab. Distrib. Act. Arch. Cent., Oak Ridge, TN, 2012.

Tietje, O. and Hennings, V.: Accuracy of the saturated hydraulic conductivity prediction by pedo-transfer functions compared to the variability within FAO textural classes, Geoderma, 69, 7184, https://doi.org/10.1016/0016-7061(95)00050-X, 1996.

Uddin, J., Smith, R. J., Hancock, N. H., and Foley, J. P.: Evaporation and sapflow dynamics during sprinkler irrigation of cotton, Agric. Water Manage., 125, 35-45, https://doi.org/10.1016/j.agwat.2013.04.001, 2013.

USBR: Technical Memorandum Yakima River Basin Study - WaterSMART Program Subtask 2.1, Tech. Memo. Yakima River Basin Study - WaterSMART Program Subtask 21, 2010.

Vano, J. A., Scott, M. J., Voisin, N., Stöckle, C. O., Hamlet, A. F., Mickelson, K. E. B., Elsner, M. M., and Lettenmaier, D. P.: Climate change impacts on water management and irrigated agriculture in the Yakima River Basin, Washington, USA, Climatic Change, 102, 287-317, https://doi.org/10.1007/s10584010-9856-z, 2010.
Vérant, S., Laval, K., Polcher, J., and De Castro, M.: Sensitivity of the Continental Hydrological Cycle to the Spatial Resolution over the Iberian Peninsula, J. Hydrometeorol., 5, 267-285, https://doi.org/10.1175/15257541(2004)005<0267:SOTCHC>2.0.CO;2, 2004.

Verzano, K., Bärlund, I., Flörke, M., Lehner, B., Kynast, E., Voß, F., and Alcamo, J.: Modeling variable river flow velocity on continental scale: Current situation and climate change impacts in Europe, J. Hydrol., 424-425, 238-251, https://doi.org/10.1016/j.jhydrol.2012.01.005, 2012.

Waha, K., Müller, C., Bondeau, A., Dietrich, J. P., Kurukulasuriya, P., Heinke, J., and Lotze-Campen, H.: Adaptation to climate change through the choice of cropping system and sowing date in sub-Saharan Africa, Global Environ. Change, 23, 130-143., https://doi.org/:0.1016/j.gloenvcha.2012.11.001, 2013.

Wei, J., Dirmeyer, P. A., Wisser, D., Bosilovich, M. G., and Mocko, D. M.: Where Does the Irrigation Water Go? An Estimate of the Contribution of Irrigation to Precipitation Using MERRA, J. Hydrometeorol., 14, 275-289, https://doi.org/10.1175/JHM-D-12079.1, 2013.

Wheeler, T. and von Braun, J.: Climate Change Impacts on Global Food Security, Science, 341, 508-513, https://doi.org/10.1126/science.1239402, 2013.

Williams, J. R., Renard, K. G., and Dyke, P. T.: EPIC: A new method for assessing erosion's effect on soil productivity, J. Soil Water Conserv., 38, 381-383, 1983.

Williams, J. R., Jones, C. A., Kiniry, J. R., and Spanel, D. A.: The EPIC crop growth model, T. ASAE, 32, 497-511, 1989.

Wilson, K., Goldstein, A., Falge, E., Aubinet, M., Baldocchi, D., Berbigier, P., Bernhofer, C., Ceulemans, R., Dolman, H., Field, C., Grelle, A., Ibrom, A., Law, B. E., Kowalski, A., Meyers, T., Moncrieff, J., Monson, R., Oechel, W., Tenhunen, J., Valentini, R., and Verma, S.: Energy balance closure at FLUXNET sites, FLUXNET 2000 Synthesis, Agr. Forest Meteorol., 113, 223243, https://doi.org/10.1016/S0168-1923(02)00109-0, 2002.

Wisser, D., Fekete, B. M., Vörösmarty, C. J., and Schumann, A. H.: Reconstructing 20th century global hydrography: a contribution to the Global Terrestrial Network-Hydrology (GTN-H), Hydrol. Earth Syst. Sci., 14, 1-24, https://doi.org/10.5194/hess14-1-2010, 2010.

Yonts, C.D., Kranz, W.L., Martin, D.L., 2000. Water Loss from above-canopy and in-canopy sprinklers. Cooperative Extension, Institute of Agriculture and Natural Resources, University of Nebraska-Lincoln.

Yorgey, G. G., Rajagopalan, K., Chinnayakanahalli, K., Brady, M. P., Barber, M. E., Nelson, R., Stockle, C. O., Kruger, C. E., Dinesh, S., Malek, K., and Yoder, J.: Columbia River Basin Long-Term Water Supply and Demand Forecast, available at: http://www.ecy.wa.gov/biblio/1112011.html (last access: 3 April 2013), 2011.

Yuan, F., Xie, Z., Liu, Q., Yang, H., Su, F., Liang, X., and Ren, L.: An application of the VIC-3L land surface model and remote sensing data in simulating streamflow for the Hanjiang River basin, Can. J. Remote Sens., 30, 680-690, https://doi.org/10.5589/m04-032, 2004.

Zagona, E. A., Fulp, T. J., Shane, R., Magee, T., and Goranflo, H. M.: Riverware: A Generalized Tool for Complex Reservoir System Modeling, J. Am. Water Resour. Assoc., 37, 913-929, https://doi.org/10.1111/j.1752-1688.2001.tb05522.x, 2001. 
Zeng, X., Drewniak, B. A., and Constantinescu, E. M.: Calibration of the Crop model in the Community Land Model, Geosci. Model Dev. Discuss., 6, 379-398, https://doi.org/10.5194/gmdd6-379-2013, 2013.
Zhao, R. J., Zhang, Y. L., and Fang, L. R.: The Xinanjiang model Hydrological Forecasting Proceedings Oxford Symposium, IASH, Oxford, 1980. 